\title{
AGR-1 Fuel Product Specification and Characterization Guidance
}

Charles M Barnes

April 2006

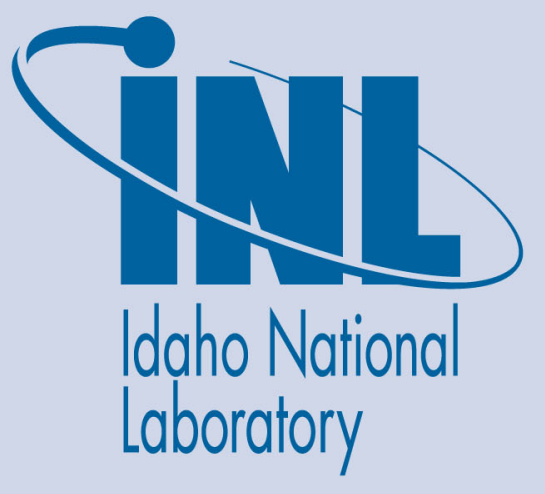

The INL is a U.S. Department of Energy National Laboratory operated by Battelle Energy Alliance 


\title{
AGR-1 Fuel Product Specification and Characterization Guidance
}

\author{
Charles M Barnes
}

April 2006

Idaho National Laboratory Idaho Falls, Idaho 83415

http://www.inl.gov

\author{
Prepared for the \\ U.S. Department of Energy \\ Under DOE Idaho Operations Office \\ Contract Unknown
}


1. Title: AGR-1 Fuel Product Specification and Characterization Guidance

2. Index Codes:

Building/Type

SSC ID

Site Area

3. NPH Performance Category:

4. EDF Safety Category:

or $\triangle \mathrm{N} / \mathrm{A}$

5. Summary:

The Preliminary Advanced Gas Reactor (AGR) Fuel Specification (EDF-4198, Rev. 1) issued in April 2004 provided the full range of characterization information desirable on advanced gas reactor fuel to be manufactured as part of the AGR Fuel Development and Qualification Program.

This AGR-1 Fuel Product Specification provides the specific product requirements necessary for acceptance of the fuel manufactured for the AGR-1 irradiation test. Guidance on additional, desirable characterization data that should be obtained to support process development and process modeling activities is also provided but not listed as product requirements.

One change was made in Revision 8. The selection of variant 3 was finalized, based on results of coating development runs and the recommendation of the TCT March $16^{\text {th }}, 2006$. Variant 3 will use an argon/hydrogen mixture and a reduced temperature for the $\mathrm{SiC}$ layer.

6. Review (R) and Approval (A) and Acceptance (Ac) Signatures: (See instructions for definitions of terms and significance of signatures.)

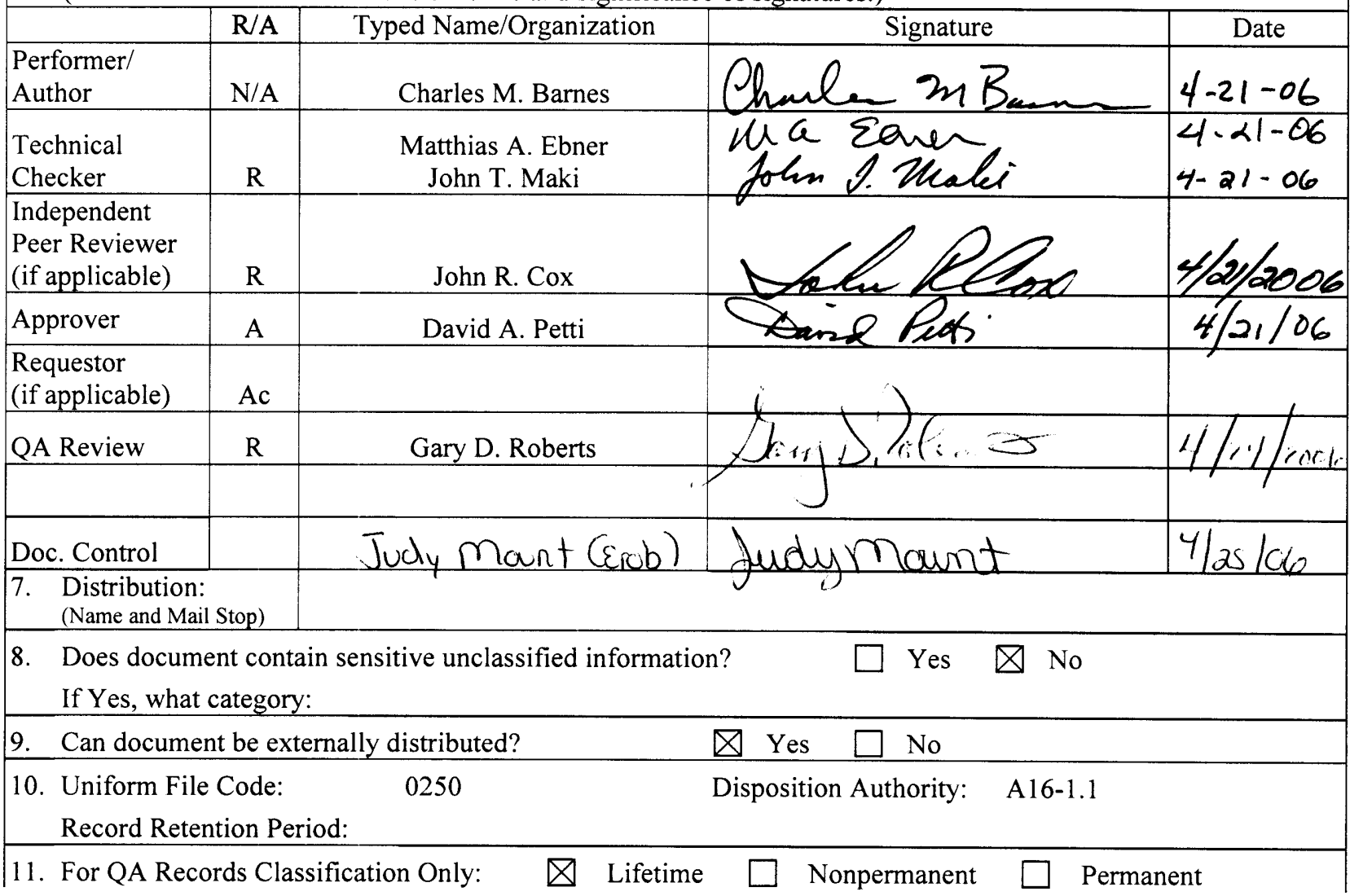


EDF No.: $\mathbf{4 3 8 0}$

EDF Rev. No.: 8

Project File No.: 23841

1. Title: AGR-1 Fuel Product Specification and Characterization Guidance

2. Index Codes:

Building/Type

SSC ID

Site Area

Item and activity to which the QA Record apply:

AGR Fuel Development and Qualification Program NGNP Reactor Project

12. NRC related? $\square$ Yes $\square$ No

13. Registered Professional Engineer's Stamp (if required) 


\section{AGR-1 Fuel Product Specification And Characterization Guidance}

\section{Introduction}

This document presents the product requirements for the AGR-1 irradiation test fuel and variants. This document also describes additional fuel characterization information to be provided (to the extent possible) to support process development and process modeling activities. This specification and characterization guidance document is considered a subset of EDF-4198, Preliminary AGR Fuel Specification (Rev. 1), issued in April, 2004. ${ }^{1}$

Product requirements for AGR-1 are presented for the baseline fuel and variants for irradiation in the capsule. Process parameters for the baseline and variant particles are based on the results of a series of coating runs using natural uranium UCO kernels. These results were reviewed by the Technical Coordination Team (TCT) to select the conditions for the baseline and variant particles to be used in AGR-1 tests.

Product requirements are defined for the fuel kernels, the coated particles, and the fuel compacts used for irradiation. Although complete information on individual coating layers is highly desirable, it may not be feasible for a continuous uninterrupted process. For some coating layer requirements, the property may need to be determined to the required confidence level using interrupted runs. The process parameters would then be subsequently locked for fabrication of the AGR fuel particles. Particle characterization information will be gathered recognizing the priorities set by the TCT. Characterization of coated particles to determine properties other than those specified may be performed for information only and will not represent product acceptance requirements.

Product specifications with \pm values represent an allowable range for the mean and are not standard deviations of the specification.

\section{Quality Assurance}

During the manufacturing, handling and shipping of the fuel described in this specification, a documented quality assurance program shall be in effect. Kernels for AGR-1 fuel were produced at BWXT under a quality program which conformed to the requirements of NQA-1 1997, as per the earlier revision of this specification in effect at the time of kernel fabrication. For coated particles and compacts, the quality program shall conform to the requirements of the NQA-1 2000 as implemented and documented by the fuel fabricator's quality assurance program plan. To achieve the compliance with the quality requirements, each organization that performs operations on the product shall utilize qualified personnel, controlled processes, and measurement techniques that are traceable to recognized industry standards. 
Where sampling and statistical procedures are to be used in place of $100 \%$ inspection in verifying compliance with acceptance criteria, all statistical procedures shall have a confidence level of $95 \%$ or as indicated in the tables in this document. Statistical sampling guidance for meeting the required confidence levels is available in EDF-4542. ${ }^{2}$ Where acceptance criteria are given for both the mean and the distribution of an attribute, statistical procedures shall be applied separately for each criterion. Many standard statistical procedures assume that the property under consideration has a normal distribution in the population of interest. Caution must be exercised with applying such procedures to non-normal distributions. However, for now, normality will be assumed without a requirement for validation. The assumption of normality is discussed further in the Statistical Methods Handbook for Advanced Gas Reactor Fuel Materials. ${ }^{8}$

\section{Baseline and Variant Process Conditions}

The AGR-1 irradiation will include a total of six capsules containing baseline and variant fuels. Two capsules will contain baseline fuel and four capsules variant fuels. Coater conditions for producing the baseline fuel and variant particles were selected by the TCT based on characterization data of particles from a series of small-coater runs using NUCO particles. The goal of defining a baseline fuel was to identify a set of process conditions that would produce fuel considered to have the best prospects for successful performance in the AGR-1 irradiation as well as post-irradiation examination and testing. The purpose of irradiation variant fuels is to determine if certain deviations from baseline process conditions result in improved performance. To select conditions for the IPyC layer, data from 20 coater runs made at temperatures from $1170^{\circ} \mathrm{C}$ to $1325^{\circ} \mathrm{C}$ and three coating gas fractions $(0.15,0.3$ and 0.45$)$ were reviewed. Characterization data of particles from these runs plus additional characterization of particles after the $\mathrm{SiC}$ coating layer was applied were used to select the baseline and variant fuels. The selection of baseline and variant fuels is documented in the notes of the May 10, 2005 TCT Meeting, and is briefly summarized below.

\subsection{Baseline Process Conditions}

Because of the excellent performance of historic German fuel, process conditions for German fuel provided a starting point for selecting the baseline fuel. Data from an IPyC parametric study was used to refine these conditions for the specific coater that will be used to produce AGR-1 particles. Characteristics of the IPyC layer present the greatest risk of fuel failure during irradiation. IPyC dimensional stability under irradiation, as inferred by the properties of surface connected porosity and anisotropy, is improved by increasing temperature and coating gas fraction. Conversely, IPyC permeability, which can lead to $\mathrm{SiC}$ defects during coating or $\mathrm{SiC}$ chemical attack during irradiation, is improved (reduced) by decreasing coating temperature and coating gas fraction. The characterization data from the parametric study shows particles produced in a fairly narrow range of conditions have a high likelihood of successful performance. The conditions for the baseline fuel are shown in Table 3.1: 
Table 3.1: Baseline Fuel Conditions

\begin{tabular}{|c|c|c|c|c|}
\hline & Buffer & $\underline{\mathrm{IPyC}}$ & $\underline{\mathrm{SiC}}$ & OPyC \\
\hline Coating gas temperature ${ }^{(\text {Note I) }}$ & $1450^{\circ} \mathrm{C}$ & $1265^{\circ} \mathrm{C}$ & $1500^{\circ} \mathrm{C}$ & $1290^{\circ} \mathrm{C}$ \\
\hline Coating gas fraction & $0.60 \pm 0.10$ & $0.30 \pm 0.03$ & $1.5 \pm 0.5 \% \mathrm{MTS}$ & $0.30 \pm 0.03$ \\
\hline Coating gas ratio $^{(\text {Note 2) }}$ & NA & $0.85 \pm 0.085$ & NA & NA \\
\hline Coating rate, $\mu \mathrm{m} / \mathrm{min}$ & $\sim 20$ & $\sim 3.0$ & $\sim 0.25$ & $\sim 3.0$ \\
\hline Coating density, $\mathrm{g} / \mathrm{cm}^{3}$ & $\sim 1.05$ & $\sim 1.9$ & NA & $\sim 1.9$ \\
\hline
\end{tabular}

\subsection{Variant Process Conditions}

While the goal of the baseline process is to replicate properties of historic German TRISOcoated particles, and thereby achieve superior irradiation performance, producing and testing particles with slightly different properties may lead to new understanding and further improvements in irradiation performance.

Variants 1 and 2 were selected to increase the prospects for successful pyrocarbon performance in at least one capsule. Variant 1 increases the IPyC coating temperature by $25^{\circ} \mathrm{C}$ relative to the baseline fuel. This change is expected to enhance irradiation dimensional stability at the expense of increased uranium dispersion. The IPyC density is expected to be about $1.85 \mathrm{~g} / \mathrm{cm}^{3}$ for Variant 1 , lower than the baseline but still above the lower critical region limit of $1.80 \mathrm{~g} / \mathrm{cm}^{3}$. Variant 2 increases the IPyC coating gas fraction from 0.30 to 0.45 at the baseline coating temperature of $1265^{\circ} \mathrm{C}$. The increase in coating gas fraction is expected to increase irradiation dimensional stability without significantly increasing uranium dispersion or layer density. This increase in coating gas fraction will cause an increase in the coating rate.

For Variant 3, the carrier gas composition of the $\mathrm{SiC}$ layer is to be changed from the baseline $100 \%$ hydrogen to an argon-hydrogen mixture and the coating temperature reduced to about $1400^{\circ} \mathrm{C}$. Based on earlier ORNL studies and historical data from the UK Dragon project, these conditions are expected to produce a $\mathrm{SiC}$ microstructure similar to historical German fuel. The reduced $\mathrm{SiC}$ coating temperature has the potential benefit of reducing uranium dispersion during coating. The Ar to hydrogen ratio and temperature can be adjusted to meet the $\mathrm{SiC}$ microstructure and other product specifications. 
Table 3.2: Variant Fuel Conditions

\begin{tabular}{|c|l|}
\hline Variant & Change from Baseline Conditions \\
\hline 1 & IPyC coating temperature $=1290 \pm 25^{\circ} \mathrm{C}$ \\
\hline 2 & IPyC coating gas fraction $=0.45 \pm 0.03$ \\
\hline 3 & $\mathrm{SiC}$ carrier gas $=\mathrm{Ar}+\mathrm{H}_{2} ; \mathrm{SiC}$ coating temperature $=\sim 1400^{\circ} \mathrm{C}$ \\
\hline
\end{tabular}

\section{Fuel Kernel Specifications}

\subsection{Kernel Batch Specifications}

Individual kernel batches shall meet the requirements of Table 4.1 prior to their acceptance for inclusion in a kernel composite.

Table 4.1: Specifications for Kernel Batches

\begin{tabular}{|c|c|c|c|c|}
\hline Kernel Property & Mean $^{(a)}$ & $\begin{array}{l}\text { Critical } \\
\text { Region }^{(a)}\end{array}$ & $\begin{array}{l}\text { Fraction in } \\
\text { Critical } \\
\text { Region }\end{array}$ & Comments \\
\hline \multicolumn{5}{|c|}{ Variable Properties } \\
\hline $\begin{array}{l}\text { Envelope density } \\
\left(\mathrm{Mg} / \mathrm{m}^{3}\right)\end{array}$ & $\geq 10.3$ & not specified & not specified & \\
\hline Diameter $(\mu \mathrm{m})$ & $350 \pm 20$ & not specified & not specified & \\
\hline \multicolumn{5}{|c|}{ Attribute Properties } \\
\hline Sphericity (ellipticity) & not specified & $\geq 1.06$ & $\leq 0.10$ & \\
\hline \multicolumn{5}{|c|}{ Measurement Only } \\
\hline Microstructure & not specified & not specified & not specified & $\begin{array}{l}\text { Samples must } \\
\text { demonstrate evidence } \\
\text { of presence of oxidic } \\
\text { and carbidic phases }\end{array}$ \\
\hline
\end{tabular}

Table 4.1 notes:

(a) Specified mean values and fraction in critical regions determined at the $95 \%$ confidence level. The \pm values represent an allowable range for the mean value and are not standard deviations of the mean.

\subsection{Kernel Composite Specifications}

The kernel composite shall consist of multiple kernel batches combined and thoroughly mixed to ensure uniformity prior to sampling for acceptance. A minimum or maximum size of a fuel kernel composite is not specified, however, a fuel kernel composite for use in AGR-1 is expected to contain about 3.5 kilograms of kernels. The kernel composite specifications are shown in Table 4.2. 
Table 4.2: Specifications for Kernel Composites

\begin{tabular}{|c|c|c|c|c|}
\hline Kernel Property & Mean $^{(a)}$ & $\begin{array}{l}\text { Critical } \\
\text { Region }^{(a)}\end{array}$ & $\begin{array}{l}\text { Fraction of } \\
\text { composite kernels in } \\
\text { Critical Region }\end{array}$ & Comments \\
\hline \multicolumn{5}{|c|}{ Variable Properties } \\
\hline $\begin{array}{l}\text { U-235 enrichment } \\
\text { (wt \%) }\end{array}$ & $19.80 \pm 0.10$ & not specified & not specified & \\
\hline $\begin{array}{l}\text { Carbon/uranium } \\
\text { (atomic ratio) }\end{array}$ & $0.50 \pm 0.20$ & $\begin{array}{l}\leq 0.20 \\
\geq 0.80 \\
\end{array}$ & $\begin{array}{l}\leq 0.01 \\
\leq 0.01\end{array}$ & \\
\hline $\begin{array}{l}\text { Oxygen/uranium } \\
\text { (atomic ratio) }\end{array}$ & $1.50 \pm 0.20$ & not specified & not specified & \\
\hline $\begin{array}{l}\text { (Carbon plus } \\
\text { oxygen)/uranium } \\
\text { (atomic ratio) }\end{array}$ & $\leq 2.0$ & not specified & not specified & \\
\hline $\begin{array}{l}\text { Individual impurities: } \\
\mathrm{Li}, \mathrm{Na}, \mathrm{Ca}, \mathrm{V}, \mathrm{Cr}, \mathrm{Mn} \text {, } \\
\mathrm{Fe}, \mathrm{Co}, \mathrm{Ni}, \mathrm{Cu}, \mathrm{Zn}, \mathrm{Al} \text {, } \\
\& \mathrm{Cl} \text { (ppm-wt) }\end{array}$ & $\begin{array}{l}\leq 100 \text { each } \\
\text { impurity }\end{array}$ & not specified & not specified & \\
\hline $\begin{array}{l}\text { Process Impurities: P, S } \\
\text { (ppm-wt) }\end{array}$ & $\begin{array}{l}\leq 1500 \text { each } \\
\text { impurity }\end{array}$ & not specified & not specified & \\
\hline $\begin{array}{l}\text { Envelope density } \\
\left(\mathrm{Mg} / \mathrm{m}^{3}\right)\end{array}$ & $\geq 10.4$ & not specified & not specified & \\
\hline Diameter $(\mu \mathrm{m})$ & $350 \pm 10$ & $\begin{array}{l}<300 \\
>400 \\
\end{array}$ & $\begin{array}{l}\leq 0.01 \\
\leq 0.01\end{array}$ & \\
\hline $\begin{array}{l}\text { Total uranium } \\
\text { (wt \%) }\end{array}$ & $\geq 87.0$ & not specified & not specified & \\
\hline \multicolumn{5}{|c|}{ Attribute Properties } \\
\hline Sphericity (ellipticity) & not specified & $\geq 1.05$ & $\leq 0.10$ & \\
\hline \multicolumn{5}{|c|}{ Measurement Only } \\
\hline $\begin{array}{l}\text { Microstructure and } \\
\text { morphology }\end{array}$ & not specified & not specified & not specified & \\
\hline Surface area & not specified & not specified & not specified & \\
\hline
\end{tabular}

Table 4.2 notes:

(a) Specified mean values and fraction in critical regions determined at the $95 \%$ confidence level. The \pm values represent an allowable range for the mean value and are not standard deviations of the mean. 


\section{TRISO Coated Fuel Particle Specifications}

For the purposes of the AGR-1 fuel product specification, a coating batch shall be considered the same as a single coating run. A coated particle composite will normally include the material from a minimum of three coating runs or the total quantity of material made to the specific process involved. ${ }^{a}$

\subsection{Finished Fuel Particle Batch Sorting Specifications}

Because baseline fuel particles are coated in a continuous uninterrupted processing sequence, all defects resulting from particle sticking or other abnormal interaction with the coating system will be contained in the coating batch. The following initial sorting steps shall be performed prior to batch sampling.

\subsubsection{Sieving or Rolling to Remove Undersize and Oversize Particles}

Each batch of coated particles shall be double-sieved with electroformed sieves to remove all particles that pass through a $700 \mu \mathrm{m}$ sieve and all particles that do not pass through an $850 \mu \mathrm{m}$ sieve. Sieves used for this operation shall be checked and verified to be undamaged and without measurable wear. Alternatively, the particles can be size-classified using a roller micrometer that achieves results equivalent to or better than sieving.

\subsubsection{Tabling to Remove Highly Aspherical Particles}

An inclined vibrating tabling process shall be used to sort aspherical particles from spherical particles. The table surface shall have a surface finish no coarser than 63 microinch. The operation shall be adjusted such that particle flow onto the table is slow enough that particle interference does not change the results.

\subsection{Coated Particle Batch Specifications}

Each coating batch shall be tested prior to its inclusion in a coated particle composite.

Table 5.1: Specifications for Coated Particle Batches

\begin{tabular}{|l|l|l|}
\hline Coated Particle Property & Mean $^{(\mathrm{a})}$ & Comments \\
\hline \multicolumn{3}{|c|}{ Variable Properties } \\
\hline Buffer thickness $(\mu \mathrm{m})$ & $100 \pm 15$ & \\
\hline IPyC thickness $(\mu \mathrm{m})$ & $40 \pm 5$ & \\
\hline SiC thickness $(\mu \mathrm{m})$ & $35 \pm 4$ & \\
\hline OPyC thickness $(\mu \mathrm{m})$ & $40 \pm 5$ & \\
\hline \multicolumn{2}{|c|}{ Attribute Properties } \\
\hline Missing OPyC layers ${ }^{(\mathrm{b})}$ (fraction) & $\leq 6.0 \times 10^{-4}$ & \\
\hline
\end{tabular}

Table 5.1 notes:

\footnotetext{
${ }^{a}$ The total quantity of material made to specific AGR-1 coating variants may be less than three coating runs.
} 
(a) Specified batch mean values are determined at the $95 \%$ confidence level. The \pm values represent an allowable range for the mean value and are not standard deviations of the mean.

(b) Nondestructive visual examination for missing OPyC layer (exposed SiC layer).

\subsection{Coated Particle Composite Product Specifications}

Coated particle composites will normally include the material from a minimum of three batches. The composite quality control testing and analysis are used to qualify the coated particle composite for reactor use. The fuel particle composites shall meet the requirements of Table 5.2.

Table 5.2: Specifications for Coated Particle Composites

\begin{tabular}{|c|c|c|c|c|}
\hline $\begin{array}{l}\text { Coated Particle } \\
\text { Property }\end{array}$ & Mean $^{(\mathrm{a})}$ & $\begin{array}{l}\text { Critical } \\
\text { Region }^{(a)}\end{array}$ & $\begin{array}{l}\text { Fraction of } \\
\text { particle } \\
\text { composite in } \\
\text { Critical } \\
\text { Region }\end{array}$ & Comments \\
\hline \multicolumn{5}{|c|}{ Variable Properties } \\
\hline $\begin{array}{l}\text { Buffer thickness } \\
(\mu \mathrm{m})\end{array}$ & $100 \pm 15$ & $\leq 55$ & $\leq 0.01$ & \\
\hline $\begin{array}{l}\text { IPyC thickness } \\
(\mu \mathrm{m})\end{array}$ & $40 \pm 4$ & $\begin{array}{l}\leq 30 \\
\geq 56\end{array}$ & $\begin{array}{l}\leq 0.01 \\
\leq 0.01\end{array}$ & \\
\hline $\begin{array}{l}\text { SiC thickness } \\
(\mu \mathrm{m})\end{array}$ & $35 \pm 3$ & $\leq 25$ & 0.01 & \\
\hline $\begin{array}{l}\text { OPyC thickness } \\
(\mu \mathrm{m})\end{array}$ & $40 \pm 4$ & $\leq 20$ & $\leq 0.01$ & \\
\hline $\begin{array}{l}\text { Buffer bulk density }{ }^{(\mathrm{c})} \\
\left(\mathrm{Mg} / \mathrm{m}^{3}\right)\end{array}$ & $1.03 \pm 0.15$ & not specified & not specified & \\
\hline $\begin{array}{l}\text { IPyC density } \\
\left(\mathrm{Mg} / \mathrm{m}^{3}\right)\end{array}$ & $1.90 \pm 0.05$ & $\begin{array}{l}\leq 1.80 \\
\geq 2.00\end{array}$ & $\begin{array}{l}\leq 0.01 \\
\leq 0.01\end{array}$ & \\
\hline $\begin{array}{l}\text { SiC density } \\
\left(\mathrm{Mg} / \mathrm{m}^{3}\right)\end{array}$ & $\geq 3.19$ & $\leq 3.17$ & $\leq 0.01$ & \\
\hline $\begin{array}{l}\text { OPyC density }{ }^{(\mathrm{h}, \mathrm{j})} \\
\left(\mathrm{Mg} / \mathrm{m}^{3}\right)\end{array}$ & $1.90 \pm 0.05$ & $\begin{array}{l}\leq 1.80 \\
\geq 2.00\end{array}$ & $\begin{array}{l}\leq 0.01 \\
\leq 0.01\end{array}$ & \\
\hline $\begin{array}{l}\text { IPyC anisotropy }^{(\mathrm{g})} \\
\left(\mathrm{BAF}_{\mathrm{o}}\right)\end{array}$ & $\leq 1.035$ & $\geq 1.06$ & $\leq 0.01$ & $\begin{array}{l}\text { For variants in which IPyC } \\
\text { coating conditions are } \\
\text { deliberately varied to affect } \\
\text { IPyC anisotropy, anisotropy is } \\
\text { to be measured but } \\
\text { specification does not need to } \\
\text { be met }\end{array}$ \\
\hline $\begin{array}{l}\text { OPyC anisotropy }{ }^{(\mathrm{g})} \\
\left(\mathrm{BAF}_{\mathrm{o}}\right)\end{array}$ & $\leq 1.035$ & $\geq 1.06$ & $\leq 0.01$ & \\
\hline
\end{tabular}




\begin{tabular}{|l|l|l|l|l|}
\hline \multicolumn{5}{|l|}{ Table 5.2 (Continued) } \\
\hline \multicolumn{5}{|c|}{ Attribute Properties } \\
\hline $\begin{array}{l}\text { Aspect Ratio } \\
\text { (faceting) }\end{array}$ & not specified & $\geq 1.14$ & $\leq 0.01$ & \\
\hline Defective SiC fraction & $\leq 1.0 \times 10^{-4}$ & not specified & not specified & \\
\hline $\begin{array}{l}\text { Missing OPyC layer } \\
\text { defect fraction }{ }^{(\mathrm{e})}\end{array}$ & $\leq 3.0 \times 10^{-4}$ & not specified & not specified & Attribute minimized by sorting \\
\hline $\begin{array}{l}\text { Particles with SiC gold } \\
\text { spots, }{ }^{(\mathrm{i})} \text { fraction }\end{array}$ & $\leq 5.0 \times 10^{-3}$ & not specified & not specified & $\begin{array}{l}\text { See visual standard, Figure 2; } \\
\text { Applies to variants 2 and 3a }\end{array}$ \\
\hline $\begin{array}{l}\text { Particles with SiC gold } \\
\text { spots, }{ }^{(\mathrm{i})} \text { fraction }\end{array}$ & $\leq 1.0 \times 10^{-3}$ & not specified & not specified & $\begin{array}{l}\text { See visual standard, Figure 2; } \\
\text { Applies to baseline, variant 1 and } \\
\text { variant 3b particles }\end{array}$ \\
\hline SiC microstructure & Note f & not specified & not specified & $\begin{array}{l}\text { See visual standards, Figures 1a, } \\
\text { 1b }\end{array}$ \\
\hline
\end{tabular}

Table 5.2 notes:

(a) Specified composite mean values and fraction in critical regions determined at the $95 \%$ confidence level. The \pm values represent an allowable range for the mean value and are not standard deviations of the mean.

(b) Aspect ratio is defined as the ratio of maximum to minimum diameters of the coated particle.

(c) Densities may be tested on coating layers applied using interrupted runs, prior to fuel manufacture. Samples from at least three coating runs should be tested, and measured densities of all three samples must meet the acceptance criteria. If all three measurements do not meet the criteria, three additional coating runs should be made. Also, the coater must demonstrate that the process used for the product was the same as that used for the interrupted runs.

(d) Deleted.

(e) Nondestructive visual examination for missing OPyC layer (exposed $\mathrm{SiC}$ layer).

(f) Specification will be met if the average $\mathrm{SiC}$ grain size of 3 coated-particles is judged to be smaller than the average grain size shown in the visual standards (Figures $1 \mathrm{a}$ and $1 \mathrm{~b}$ ).

(g) $\mathrm{BAF}_{\mathrm{o}}$ to be measured before compacting for acceptance criteria and again after compacting for information only.

(h) Specification values for IPyC and OPyC density correspond to those measured by the sink/float method. If another method is used, a correlation to sink/float densities must be developed.

(i) Gold spots are the optical manifestation of lenticular shaped flaws within the $\mathrm{SiC}$ coating, which, if overly large, can reduce the strength of the $\mathrm{SiC}$ and thereby increase the probability of failure during irradiation.

(j) The OPyC density shall be measured from samples of each batch of the composite. The composite will be deemed acceptable relative to OPyC density if each batch meets the acceptance criteria. 
Visual Standards for SiC microstructure:

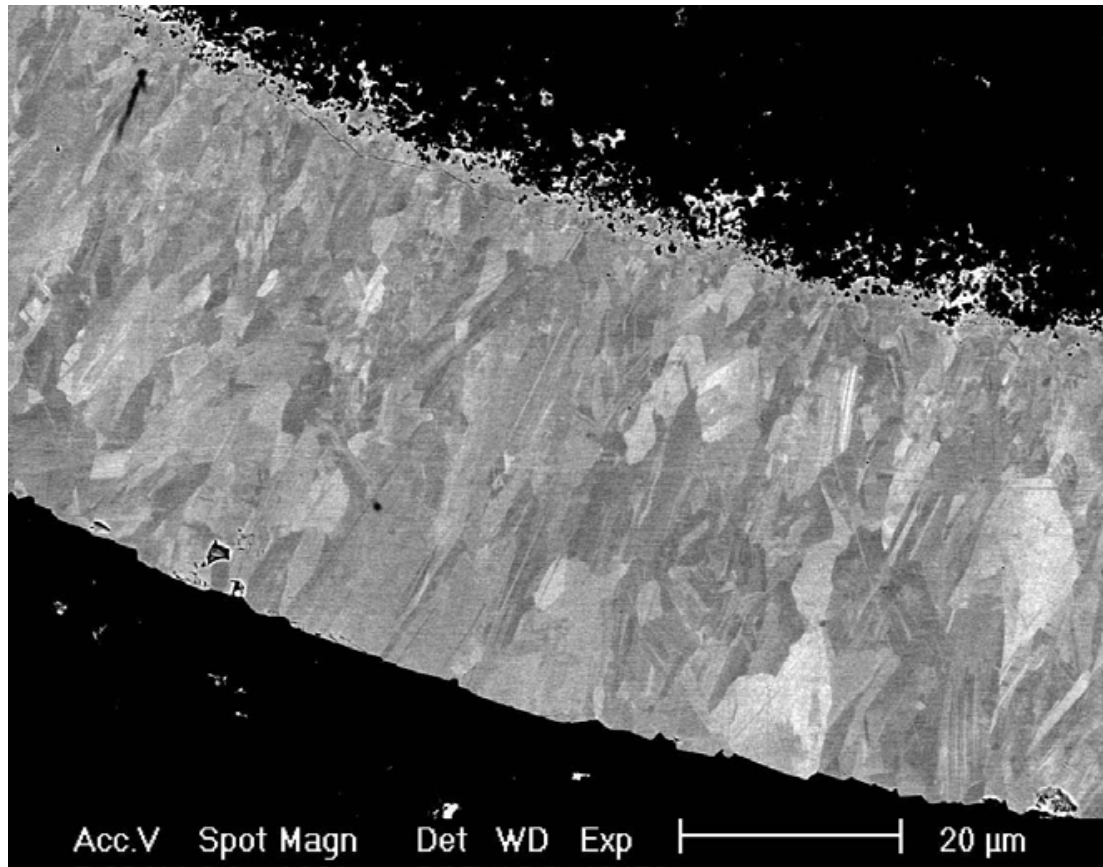

Figure 1a. SiC with too large a grain size

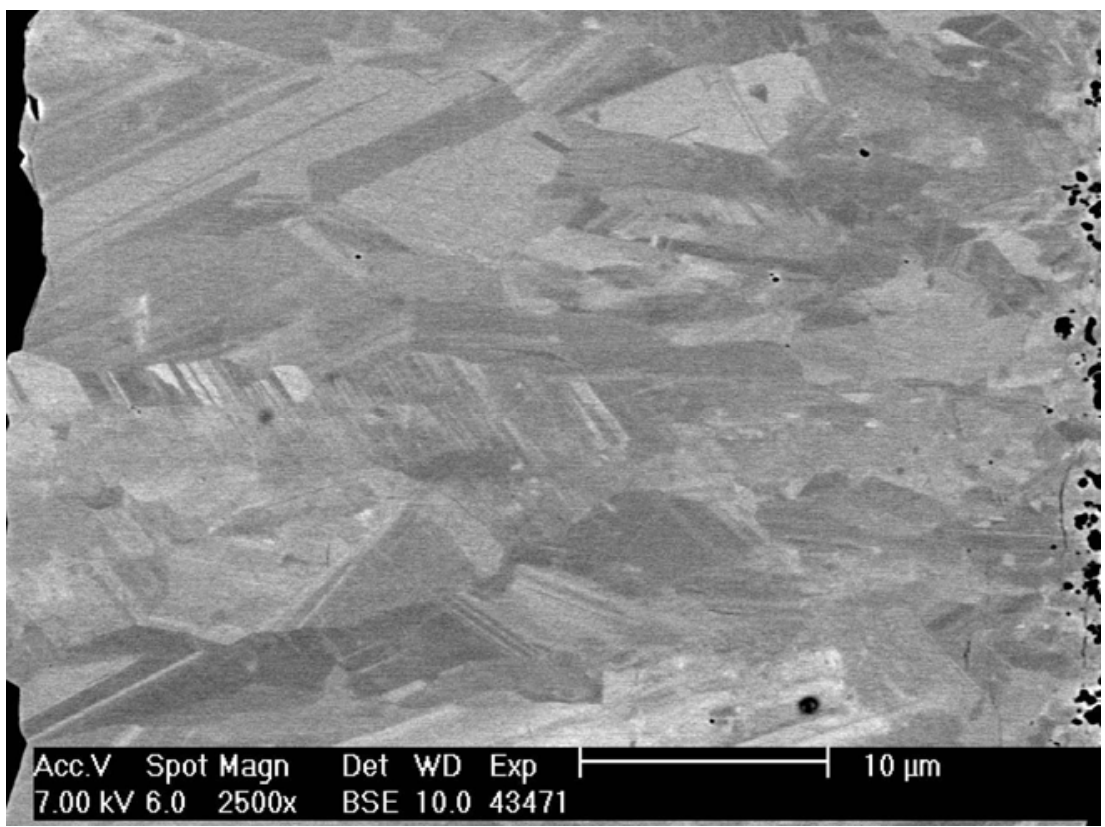

Figure $1 \mathrm{~b}$. SiC with too large a grain size 


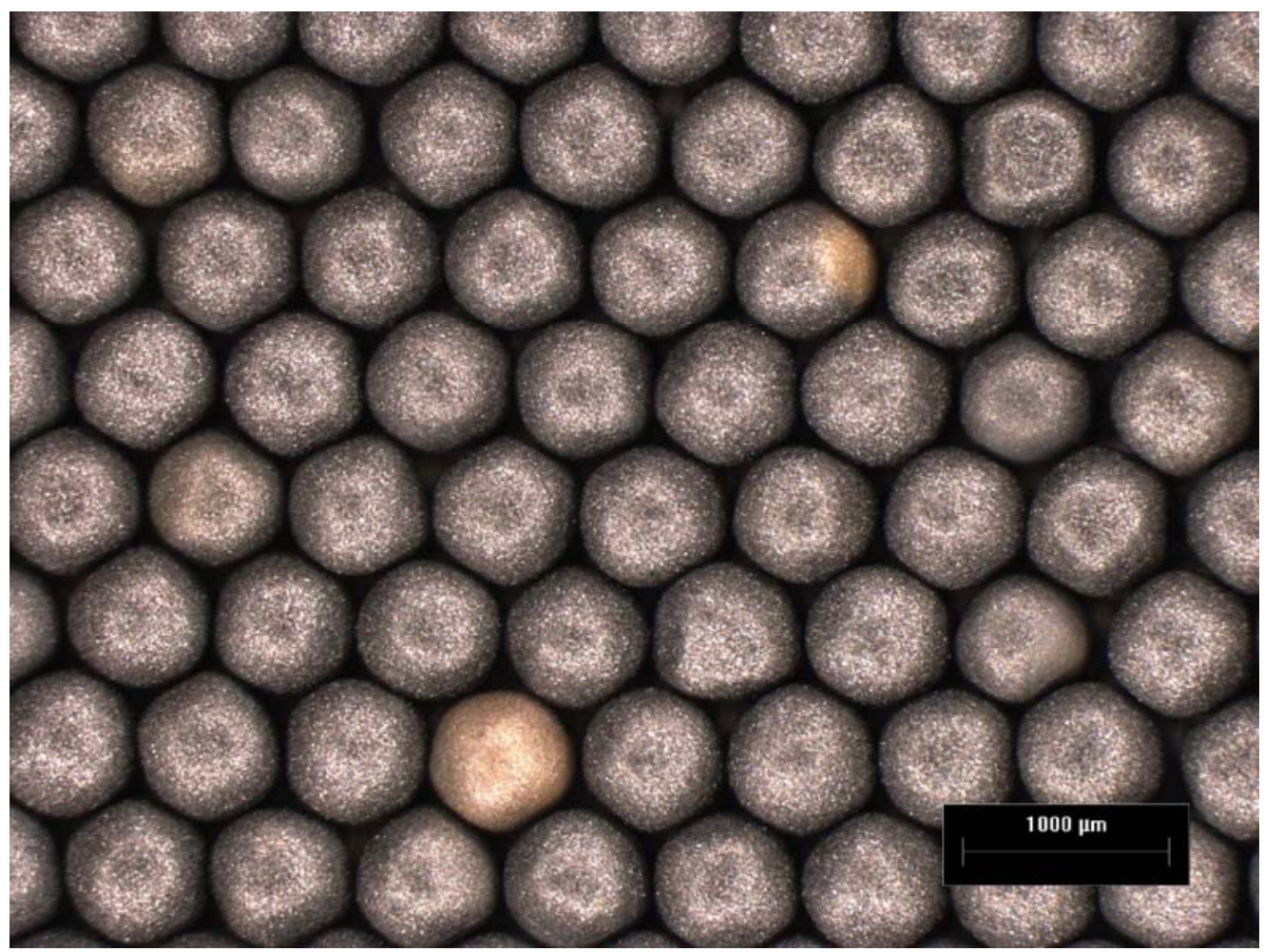

Figure 2. Visual standard for determining gold spots.

\subsection{Coated Particle Composite Characterization Guidance}

The property information listed in Table 5.3 shall be gathered to the extent feasible for historical evaluations and comparisons, fuel performance modeling, comparison with PIE data, and understanding of the coating process. These characterization items do not represent product requirements but desirable product information. 


\section{Table 5.3: Additional Characterization of Coated Particle Composites}

\begin{tabular}{|l|l|l|}
\hline Coated Particle Property & Desired Mean & Comments \\
\hline IPyC permeability & TBD & $\begin{array}{l}\text { Determine using 18-hr } \\
\text { chlorination at } 1500^{\circ} \mathrm{C}\end{array}$ \\
\hline $\begin{array}{l}\text { IPyC crystallite size } \\
(\AA)\end{array}$ & $30 \pm 10$ & $\begin{array}{l}\text { Measured with XRD or other } \\
\text { suitable method }\end{array}$ \\
\hline $\begin{array}{l}\text { OPyC crystallite size } \\
(\AA)\end{array}$ & $30 \pm 10$ & $\begin{array}{l}\text { Measured with XRD or other } \\
\text { suitable method }\end{array}$ \\
\hline IPyC microstructure & not specified & Evaluate using TEM \\
\hline OPyC microstructure & not specified & Evaluate using TEM \\
\hline $\begin{array}{l}\text { IPyC surface connected } \\
\text { porosity }\end{array}$ & $\begin{array}{l}\text { (a) } \\
\left(\mathrm{ml} / \mathrm{m}^{2}-\mathrm{PyC}\right)\end{array}$ & Measured by Hg porosimetry \\
\cline { 2 - 3 } & $\mathrm{TBD}$ & BET \\
\hline $\begin{array}{l}\text { OPyC surface connected } \\
\text { porosity }\end{array}$ & $\begin{array}{l}\text { (a) } \\
\left(\mathrm{ml} / \mathrm{m}^{2}-\mathrm{PyC}\right)\end{array}$ & Measured by Hg porosimetry \\
\cline { 2 - 3 } & $\mathrm{TBD}$ & BET \\
\hline \multirow{2}{*}{ SiC-IPyC bonding } & $\mathrm{TBD}$ & $\begin{array}{l}\text { Measure the average depth of } \\
\text { penetration of SiC into the } \\
\text { IPyC layer }\end{array}$ \\
\hline OPyC envelope density & TBD & Measured by Hg pycnometry \\
\hline
\end{tabular}

Table 5.3 notes:

(a) Surface connected porosity is by definition the volume of mercury that intrudes into the particles between $250 \mathrm{psi}(1.7 \mathrm{MPa})$ and 10,000 psi (69 $\mathrm{MPa})$.

\section{Fuel Compacting Product Specification}

\subsection{Fuel Compacting Process Limits}

The process limits listed in Table 6.1 shall be followed to ensure that the compacting process does not damage the fuel particles being compacted and does not deviate from the acceptable range of process conditions determined during development. 
Table 6.1 AGR-1 Compacting Process Limits

\begin{tabular}{|c|c|}
\hline Process & Conditions $^{\mathbf{a}}$ \\
\hline $\begin{array}{c}\text { Molding Pressure } \\
\text { (Green Compacts) }\end{array}$ & $<60 \mathrm{MPa}$ \\
\hline Carbonization & Heating rate: $<350^{\circ} \mathrm{C} / \mathrm{hr}$ in He atmosphere \\
& Hold at $950 \pm 50^{\circ} \mathrm{C}$ for $1.0 \pm 0.4 \mathrm{hrs}$. \\
& Furnace cool \\
\hline Final Heat & Heating rate approximate $20^{\circ} \mathrm{C} / \mathrm{min}$ in vacuum $(<1.3 \mathrm{~Pa})$ \\
Treatment & Hold at $1650-1850^{\circ} \mathrm{C}$ \\
& for $60 \pm 10 \mathrm{~min}$. \\
& Cool at approximate $20^{\circ} \mathrm{C} / \mathrm{min}$ to below $700^{\circ} \mathrm{C}$ \\
\hline
\end{tabular}

\subsection{Fuel Compacting Product Requirements}

Final fuel compacts for AGR-1 shall be tested to the requirements of Table 6.2.

Table 6.2. Specifications for Heat Treated Compacts

\begin{tabular}{|c|c|c|c|c|}
\hline \multirow[t]{2}{*}{ Property } & \multirow[t]{2}{*}{$\operatorname{Mean}^{(\mathrm{e})}$} & \multicolumn{2}{|c|}{ Critical Limits } & \multirow{2}{*}{$\begin{array}{l}\text { Fraction } \\
\text { Outside } \\
\text { Limits }^{(e)}\end{array}$} \\
\hline & & Lower & Upper & \\
\hline \multicolumn{5}{|c|}{ Variable Properties } \\
\hline $\begin{array}{l}\text { Mean uranium loading }{ }^{(\mathrm{f})} \text {, } \\
\text { g U/compact }\end{array}$ & $0.905 \pm 0.04$ & (a) & (a) & (a) \\
\hline Diameter, ${ }^{(\mathrm{g}, \mathrm{I})} \mathrm{mm}$ & (a) & 12.22 & 12.46 & 0 \\
\hline Length, ${ }^{(\mathrm{g})} \mathrm{mm}$ & (a) & 25.02 & 25.4 & 0 \\
\hline $\begin{array}{l}\text { Iron content, } \mu \mathrm{g} \text { Fe outside } \\
\text { of } \mathrm{SiC} \text { per compact }\end{array}$ & $\leq 25$ & (a) & 100 & 0.01 \\
\hline $\begin{array}{l}\text { Transition metal content } \\
(\mathrm{Cr}, \mathrm{Mn}, \mathrm{Co} \text {, and } \mathrm{Ni}), \mu \mathrm{g} \\
\text { outside } \mathrm{SiC} \text { per compact }\end{array}$ & $\begin{array}{l}\leq 75 \text { each } \\
\text { element }\end{array}$ & (a) & 300 total & 0.01 \\
\hline $\begin{array}{l}\text { Calcium content, } \mu \mathrm{g} \mathrm{Ca} \\
\text { outside } \mathrm{SiC} \text { per compact }\end{array}$ & $\leq 90$ & (a) & (a) & (a) \\
\hline $\begin{array}{l}\text { Aluminum content, } \mu \mathrm{g} \mathrm{Al} \\
\text { outside } \mathrm{SiC} \text { per compact }\end{array}$ & $\leq 45$ & (a) & (a) & (a) \\
\hline $\begin{array}{l}\text { Titanium }+ \text { Vanadium } \\
\text { content, } \mu \mathrm{g} \text { outside SiC per } \\
\text { compact }^{(\mathrm{h})}\end{array}$ & $\leq 400$ & (a) & (a) & (a) \\
\hline $\begin{array}{l}\text { Chlorine content, wt ppm } \mathrm{Cl} \\
\text { outside } \mathrm{SiC} \text { in compact }^{(\mathrm{i})}\end{array}$ & $\leq 30$ & (a) & (a) & (a) \\
\hline
\end{tabular}




\begin{tabular}{|c|c|c|c|c|}
\hline \multicolumn{5}{|l|}{ Table 6.2 (Continued) } \\
\hline \multicolumn{5}{|c|}{ Attribute Properties } \\
\hline $\begin{array}{l}\text { Heavy metal contamination } \\
\text { fraction, }{ }^{(j)} \mathrm{g} \text { exposed } \mathrm{U} / \mathrm{g} \mathrm{U} \\
\text { in compact }\end{array}$ & $\leq 1.0 \times 10^{-4}$ & (a) & (a) & (a) \\
\hline $\begin{array}{l}\text { Defective SiC coating } \\
\text { fraction, fraction of total } \\
\text { particles }\end{array}$ & $\leq 2.0 \times 10^{-4}$ & (a) & (a) & (a) \\
\hline $\begin{array}{l}\text { Defective IPyC coating } \\
\text { fraction, fraction of total } \\
\text { particles }^{(\mathrm{d})}\end{array}$ & $\leq 2.0 \times 10^{-4}$ & (a) & (a) & (a) \\
\hline $\begin{array}{l}\text { Defective OPyC coating } \\
\text { fraction, }{ }^{(\mathrm{k})} \text { fraction of total } \\
\text { particles }\end{array}$ & $\leq 0.01$ & (a) & (a) & (a) \\
\hline
\end{tabular}

Table 6.2 notes:

(a) Not specified.

(b) (Deleted).

(c) Determined by burn-leach test or approved alternative.

(d) Heavy metal dispersion. The visual standard for unacceptable fuel dispersion is given by Scheffel $2003,{ }^{3}$ Figure 3-2.

(e) Specified mean values and fraction in critical regions are determined at the $95 \%$ confidence level. The \pm values represent an allowable range for the mean value and are not standard deviations of the mean.

(f) Mean uranium loading based on a kernel density of $10.5 \mathrm{~g} / \mathrm{cm}^{3}$, a kernel composition of $90 \%$ uranium, mean kernel diameter, coating layer thicknesses and compact dimensions, and a packing fraction of $34.9 \%$

(g) Diameter and length measurements do not need to be performed on compacts destroyed by other QC analyses, but are required for all other compacts. Compacts that do not meet the dimension specifications can be used for archive.

(h) The $\mathrm{Ti}+\mathrm{V}$ impurity concentration specification is based on an assumed compact matrix density of $1.75 \mathrm{~g} / \mathrm{cm}^{3}$, an assumed packing fraction of particles in the compact of 0.35 and specification mean values for kernel diameter, particle layer thicknesses, particle layer thicknesses, OPyC density, compact diameter and compact length.

(i) Chlorine specification applicable only if compacts are subjected to $\mathrm{HCl}$ cleaning.

(j) Heavy metal contamination is defined as uranium that is not encapsulated by a fission gas retentive coating layer.

(k) Defective OPyC coating fraction is defined as particles with partially or completely missing OPyC layers or that have cracks.

(1) The compact diameter shall be measured at approximately the top, middle and bottom of each compact at 0 and 90 degrees. 


\section{REFERENCES}

\footnotetext{
${ }^{1}$ Petti, D. A., J. T. Maki, M. A. Ebner, G. K. Miller, Preliminary AGR Fuel Specification, EDF4198, Rev. 1, Idaho National Engineering and Environmental Laboratory, April 1, 2004.

${ }^{2}$ Einerson, J., Statistical Sampling Plan for AGR Fuel Materials, EDF-4542, Rev. 7, Idaho National Engineering and Environmental Laboratory, February 1, 2006.

${ }^{3}$ Scheffel, W., \& Saurwein, J., Preliminary Fuel Product Specifications for the Baseline Advanced Gas Reactor Fuel Design, 911034, Rev. 0 Draft, General Atomics, August 2003.

${ }^{4}$ Hunn, J. D., Results From ORNL Characterization of German Reference Fuel From EUO 2358-2365 Composite, ORNL/CF-04/06, April 2004.

${ }^{5}$ Petti, D. A., J. T. Maki, J. Buongiorno, R. R. Hobbins, G. K. Miller, Key Differences in the Fabrication, Irradiation and Safety Testing of U.S. and German TRISO-coated Particle Fuel and Their Implications on Fuel Performance, INEEL/EXT-02-00300, June, 2002.

${ }^{6}$ Saurwein, J., L. Shilling, Final Report - Testing of As-Manufactured NPR-PTF, German, and U.S Historical Fuel Particles, GA 910647, September 30, 1993.

${ }^{7}$ Clark, C. R., Microstructural Evaluation of As-Manufactured Fuel Particles, Final Report, BWED-93-032, Rev. 1, June 22, 1993.

${ }^{8}$ Einerson, J. J., Statistical Methods Handbook for Advanced Gas Reactor Fuel Materials, INL/EXT-05-00349, May 2005.
} 


\section{Appendix A}

\section{Establishing the Fuel Defect Fraction Specification and Associated Technical Basis for AGR-1 Fuel Variants ${ }^{b}$}

\section{Introduction and Purpose}

The purpose of this document is to establish the technical basis for the AGR-1 fuel defect fractions to be used in the AGR-1 fuel specification for each of the proposed variants. The fuel defect fraction specifications established for early fuel production (AGR-1 test articles) will be consistent with the objectives and priorities of the AGR-1 irradiation (shakedown of the capsule design, key critical path element of program schedule), yet deemed to be achievable in early process development and demonstrable by characterization given the funding and schedule constraints identified by the program. A number of different factors are considered in establishing the failure fraction. This document discusses those factors and compares the resultant failure fraction specification to others that have been used in past US gas reactor programs.

\section{Amount of Fuel to be Destructively Sampled Compared to the Fuel Produced in One Coating Run}

The actual population defect fraction expected in production should be below the target to have confidence that the target is met with a reasonable sample size. Too tight a fuel specification will result in significant quantities of fuel being destructively tested to demonstrate compliance with the specification. Thus, a key issue in establishing the fuel specification relates to the amount of fuel that should be destructively sampled to establish the fuel failure fraction. A 100-gram (kernel) batch from a two-inch coater will produce about 340,000 particles assuming an $80 \%$ yield after tabling. Probably three batches will be used to make a composite yielding about one million particles. ${ }^{\mathrm{c}}$ There are about 4250 particles per one-inch length compact assuming the nominal 35\% packing fraction for AGR-1 fuel. Thus, about 51,000 particles are needed for each cell in the AGR-1 capsule $(12$ compacts $x 4250=51,000)$. Thus, irradiation testing accounts for about $5 \%$ of the material in a composite.

We agree with the proposal originally made by J. Kendall to use about 100,000 particles ${ }^{\mathrm{d}}$ for burn leach analysis at the particle level and about 25 compacts for destructive leach burn leach at the compact level. These burn leach tests require about $20 \%$ of a total

\footnotetext{
${ }^{\mathrm{b}}$ Information contained in this Appendix is the result of discussions with the Technical Coordination Team on the need for specific AGR-1 defect fractions.

${ }^{c}$ Recent coater runs at ORNL have used about 60-70 g of kernels per batch, equivalent to 200,000-240,000 particles per batch, or 4-5 batches per million particles.

d Later analysis showed that specification could be met if one or no defects were found in 50,000 particles, 6 or less defects in 120,000 particles, and 13 or less defects in 220,000 particles.
} 
composite and should allow adequate material for irradiation, archiving and other QC measurements.

Meeting the remaining particle and compact specifications (e.g., missing OPyC and defective IPyC) should take less material since the missing OPyC specification has been historically met using visual inspection of particles and radiography of the residual burn leach sample to identify defective IPyC. The missing buffer specification was deleted based on calculations that indicate that sieving can remove the particles with missing or thin buffer layers.

Thus, for the 1,000,000 particles in a composite, the following allocation has been tentatively identified:

Irradiation 51,000

Burn leach of particles $\quad 110,000$

Leach burn leach of compacts $\quad 110,000$

Archive 100,000

Other QC activities 360,000 (initial placeholder - TBD by ORNL)

Remainder 270,000

This allocation suggests that if the allotment for other QC activities is too generous, then two batches might be able to be blended to form the composite. However, at the current time, we will retain the assumption that three batches will form the composite.

\section{Particle Detection in AGR-1 Versus Initial Background}

The failure rate that is selected must take into consideration the ability to detect individual particle failures in a given cell in AGR-1 relative to the initial background. The initial background consists of heavy metal contamination in the fuel matrix material and particles with exposed kernels. With approximately 50,000 particles in a test cell, the following level of initial defects can be calculated:

$\begin{array}{lc}\text { Mean Defect Fraction } & \begin{array}{r}\text { Average n } \\ \text { of failed particles }\end{array} \\ 1.0 \mathrm{E}-05 & 0.5 \\ 5.0 \mathrm{E}-05 & 2.5 \\ 1.0 \mathrm{E}-04 & 5 \\ 1.0 \mathrm{E}-03 & 50\end{array}$

Clearly, defect fractions less than 1.0E-04 are desirable. At levels approaching 1.0E-03, the background will be so high that it could probably compromise our ability to detect the details associated with a given particle failure with irradiation. Even at 1.0E-04, one particle failure adds $\sim 20 \%$ to the activity on average. Also of concern is the buildup of metallic fission products in the lines that could produce an unacceptable degree of contamination of the out-of-pile gas system with regard to subsequent irradiations. We would like to be able to not have to replace tubing outside the vessel between irradiations. 
(Note: ATR safety limits on particle failure during irradiation are even higher than those mentioned here and will not factor into our consideration about an acceptable particle failure fraction for AGR-1. This will be the subject of an independent analysis.)

\section{Ability to Fabricate High Quality Fuel}

Given that this is the first time the US has produced TRISO-coated particle fuel in over a decade, the defect fractions should not be as low as that expected from large-scale production with operators who have years of experience making such fuel. For example, the GT-MHR, the NPR, and the commercial MHTGR all had established a value of $5.0 \mathrm{x}$ $10^{-5}$ at $95 \%$ confidence as the initial $\mathrm{SiC}$ defect fraction for their reactor specification, which is equivalent to the value that HOBEG (the German fuel manufacturer) obtained from their fuel in the late 1980s. At the same time, the GA specification allowed any individual compact lot to have a value for defective $\mathrm{SiC}$ fraction that is a factor of 2 above the core average value. They did this recognizing that there is some variability from lot to lot.

\section{Final Specifications for AGR-1 Variants}

Because of the new compacting process, we have added an $\mathrm{SiC}$ defect specification at the particle level that was not used historically in production in the past. Given the need to have a definitive metric about the level of particle failures induced by the new process, this specification was considered crucial. The target defect fraction for loose particles also needs to be less than that for compacts to allow for some defect creation in compacting and the ability to quantify defects resulting from compacting. Thus, values a factor of two lower are used for defective $\mathrm{SiC}$ at the particle level.

The following defect fraction specifications have been established:

A minimum of about 100,000 particles shall be used to establish the defect level for each fuel particle and fuel compact defect in Table A-1. Pooling of data is acceptable for meeting this requirement.

Table A-1. Fuel Particle and Fuel Compact defect fractions

\begin{tabular}{|c|c|c|}
\hline \multicolumn{3}{|c|}{ Fuel Particle } \\
\hline Defect Fraction $^{(a)}$ & 95\% Confidence & Comment \\
\hline Missing $\mathrm{OPyC}$ & $3.0 \mathrm{E}-04^{(\mathrm{b})}$ & \\
\hline Defective SiC & $1.0 \mathrm{E}-04^{(\mathrm{b})}$ & New requirement \\
\hline \multicolumn{3}{|c|}{ Fuel Compact } \\
\hline Total Free Uranium $^{(\mathrm{e})}$ & $2.5 \mathrm{E}-04$ & \\
\hline HM Contamination $^{(c)}$ & $5.0 \mathrm{E}-05^{(\mathrm{d}, \mathrm{f})}$ & $20 \%$ of above \\
\hline Defective $\mathrm{SiC}^{(\mathrm{c})}$ & $2.0 \mathrm{E}-04^{(\mathrm{d})}$ & Remainder \\
\hline Defective IPyC $^{(\mathrm{c})}$ & $2.0 \mathrm{E}-04^{(\mathrm{d})}$ & \\
\hline
\end{tabular}

a. Particle composite defect fraction

b. $\quad 95 \%$ confidence that each particle composite defect fraction is $\leq$ the specified limit.

c. Fuel compact composite lot mean for that attribute

d. $95 \%$ confidence the true value for the attribute does not exceed the specified limit.

e. The sum of defective $\mathrm{SiC}$ fraction and heavy metal contamination fraction. This terminology has 
been used by Germany and Japan but not historically by the US. It is included here so that comparisons can be made.

f. HM contamination specification changed in Rev. 2 to 1.0E-04.

As shown in the figures below, for the 25 compacts ( $\sim 100,000$ particles), the value of $5.0 \times 10^{-5}$ at $95 \%$ confidence for heavy metal contamination in the fuel compact would correspond to the amount of uranium in one failed particle and still meet the specification. The figures can be used to determine the effective number of particles with a given defect for the specifications given in the table above.
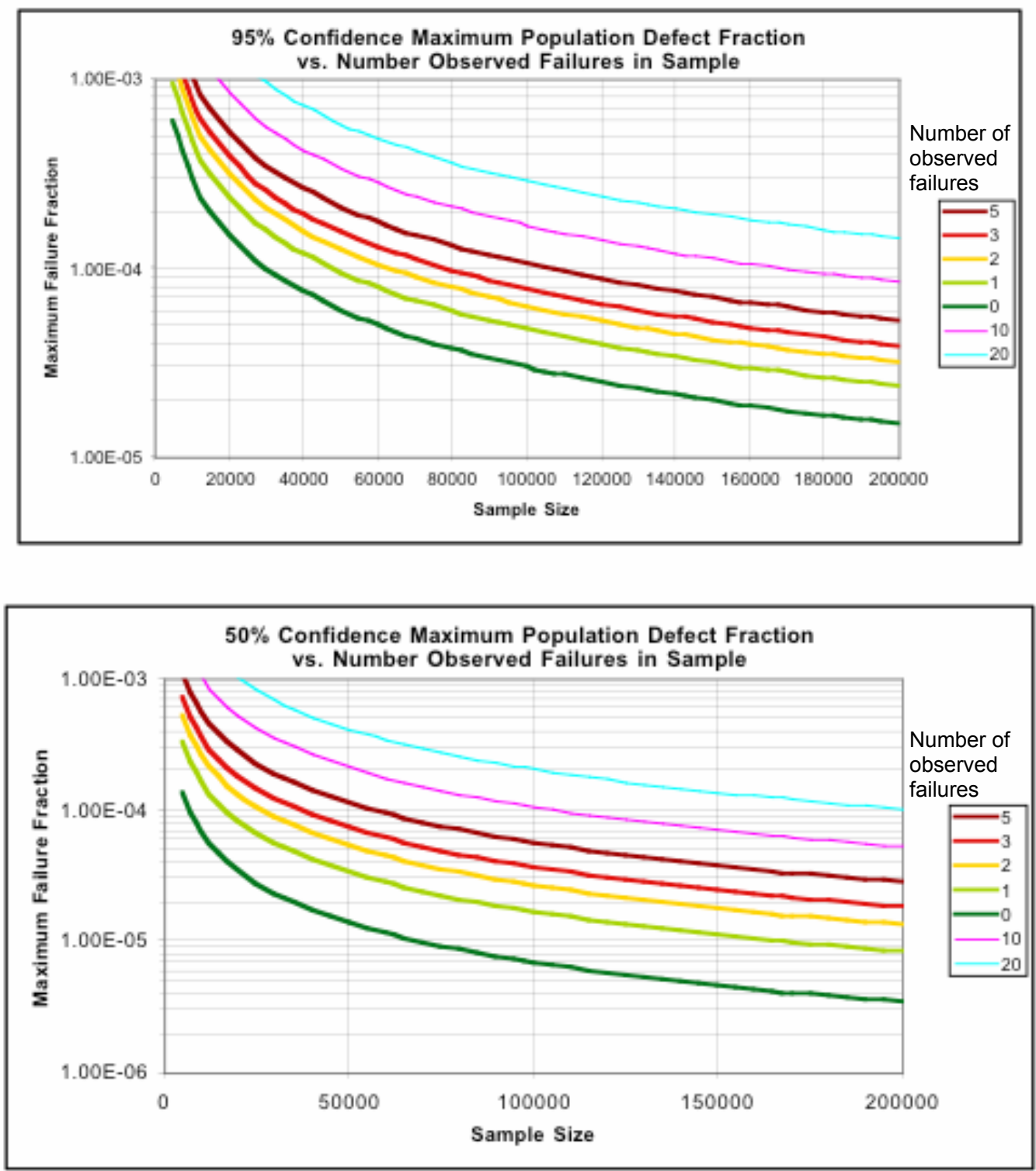

Figure A-1. Maximum Population Defect Fraction (Predicted Failure Fraction) vs. Sample Size and Number of Observed Failures in Sample. 


\section{Information Values for AGR-1 Fuel}

The following are the mean values for the specific defects based on 100,000 particles being sampled. These values can be used for capsule design and fuel performance pretest predictions until actual data are available for the fabricated material.

Table A-2. Mean Fuel Particle Defect Fractions for Use in Irradiation Capsule Design and Preliminary Fuel Performance Modeling Calculations

\begin{tabular}{|c|c|c|}
\hline Defect Fraction & Mean & Comment \\
\hline Missing Buffer & $1.0 \mathrm{E}-05$ & $\begin{array}{l}\text { Approximate value. } \\
\text { Actual mean is } \\
\text { between } 0 \text { and } 1 \text { out of } \\
110,000\end{array}$ \\
\hline Missing OPyC & $2.1 \mathrm{E}-04$ & \\
\hline Defective $\mathrm{SiC}$ & $5.0 \mathrm{E}-05$ & \\
\hline \multicolumn{3}{|c|}{ Fuel Compact } \\
\hline Total Free Uranium & $1.7 \mathrm{E}-04$ & \\
\hline HM Contamination & $1.0 \mathrm{E}-05$ & $\begin{array}{l}\text { Approximate value. } \\
\text { Actual mean is } \\
\text { between } 0 \text { and } 1 \text { out of } \\
110,000\end{array}$ \\
\hline Defective $\mathrm{SiC}$ & $1.2 \mathrm{E}-04$ & \\
\hline Defective IPyC & $1.2 \mathrm{E}-04$ & \\
\hline
\end{tabular}

\section{Comparison to Previous Specifications}

The table below compares the proposed defect fractions specifications for AGR with those for particle composites or compact lots with those proposed for GT-MHR. Values are generally a factor of two higher than for the GT-MHR. The missing OPyC specification for the GT-MHR is based on the former compacting process and not the thermosetting process that will be used in the AGR program. Thus, a comparison is not valid.

Table A-3. Comparison of AGR-1 and GT-MHR defect fraction specifications.

\begin{tabular}{|l|l|l|l|}
\hline \multicolumn{5}{|c|}{ Fuel Particle - 95\% Confidence } \\
\hline Defect Fraction & AGR & GT-MHR & Comment \\
\hline Missing Buffer & $4.0 \mathrm{E}-05$ & $2.0 \mathrm{E}-05$ & Note (a) \\
\hline Missing OPyC & $3.0 \mathrm{E}-04$ & $1.0 \mathrm{E}-03$ & \\
\hline Defective SiC & $1.0 \mathrm{E}-04$ & None & \\
\hline \multicolumn{4}{|c|}{ Fuel Compact - 95\% Confidence } \\
\hline Total Free Uranium & $2.5 \mathrm{E}-04$ & $1.2 \mathrm{E}-04$ & \\
\hline HM Contamination & $5.0 \mathrm{E}-05$ (Note b) & $2.0 \mathrm{E}-05$ & \\
\hline Defective SiC & $2.0 \mathrm{E}-04$ & $1.0 \mathrm{E}-04$ & \\
\hline Defective IPyC & $2.0 \mathrm{E}-04$ & $1.0 \mathrm{E}-04$ & \\
\hline
\end{tabular}


(a) Missing buffer specification met by sieving; screen size determined based on buffer thickness corresponding to 4.0E-05 failure fraction.

(b) HM contamination specification changed to 1.0E-04 in Rev. 2 of this specification.

Finally, it is important to note that the specifications for the NP-MHTGR and commercial MHTGR programs were compact lot values, not the core segment mean values for the corresponding reactor designs. The design also established specifications for the core mean that are a factor of 2 lower than the compact lot values. Thus, overall there is a factor of 4 between the core segment mean values for a reactor like GT-MHR and the values adopted for AGR-1. Obviously, higher quality fuel (similar to the GT-MHR compact lot values) will be needed for the performance irradiation (AGR-2) and even higher values (similar to GT-MHR core mean values) will be required for the qualification irradiations (AGR-5 and AGR-6). The values in the table appear to be a good balance for the AGR-1 irradiation considering all of the factors presented in this document. 


\section{Appendix B}

\section{Revision History}

This Revision History is provided to identify all changes and the associated justifications that have been incorporated into EDF-4380.

\subsection{REVISION 0, DATED 02/17/2004}

Initial release. The EDF was developed based on AGR programmatic goals and interpretation of existing literature resulting from previous similar programs in the United States and Germany. This initial issue formed the basis utilized by BWX Technologies, Lynchburg to fabricate and inspect prototypic fuel kernels containing natural uranium (NUCO) as a feed material.

\subsection{REVISION 1, DATED 03/17/2004}

\section{Tables 4.1 and 4.2 Sphericity}

The kernel sphericity fraction in the critical region was revised from $\leq 0.01$ to $\leq 0.10$. The BWXT method for measuring kernel diameter to determine maximum and minimum dimensions instructed the inspector to search for the maximum diameter then establish the minimum diameter as that value measured at $90^{\circ}$ to the maximum. This often included surface anomalies referred to as "pimples" or "protuberances". Conversely, if a surface anomaly commonly referred to as a "dimple" was detected, the minimum diameter was measured at the low point of the dimple and the maximum diameter was established at $90^{\circ}$ to the minimum. When using these measurements to calculate sphericity (maximum diameter divided by minimum diameter) the composited NUCO lot was rejected and BWXT initiated Quality Control Deficiency Notice (QCDN) 005. Of the 100 kernels measured, 5 exceeded the specified aspect ratio limit of 1.05. QCDN-005 was submitted to INEEL for disposition. INEEL's disposition was to re-table the composite to remove non-spherical particles. After re-tabling, the composite still failed the acceptance criteria with 3 defects and QCDN-005A was created. The INEEL Technical Team performed an in-depth evaluation that resulted in the following:

- $\quad$ A fuel kernel sphericity specification is a newly constructed requirement. The original specification was established using failure probability estimated based on finite element analyses of faceted coated particles with different aspect ratios. (see Appendix of EDF 4198) Once the critical limit on the coated particle was established, geometrical calculations were used to establish the same

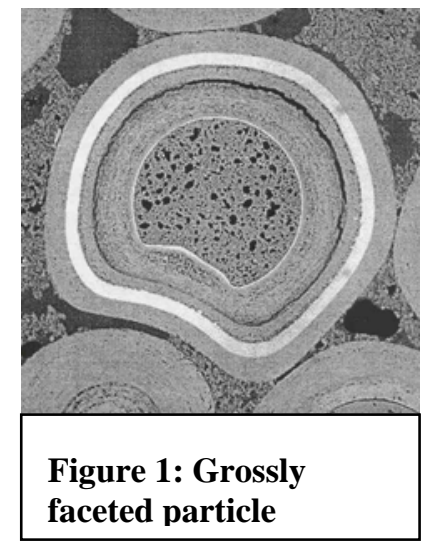


limit at the kernel level. The intent was to limit severe faceting like that shown in figure 1.

- It is clear in hindsight that the aspect ratio specification was not adequate since it caused kernels with other types of minor imperfections such as that shown in figure 2 to be rejected. This was not the intent. A more accurate specification for faceted particles is under consideration but needs development before being implemented.

- $\quad$ Historically, General Atomics did not specify kernel sphericity for the GT-MHR or for their baseline AGR fuel design. For the NP-MHTGR performance test fuel, kernel sphericity was a measurement only

requirement. However, NP-MHTGR target particles did have a kernel sphericity specification of no more than $10 \%$ of the kernels having an aspect ratio greater than

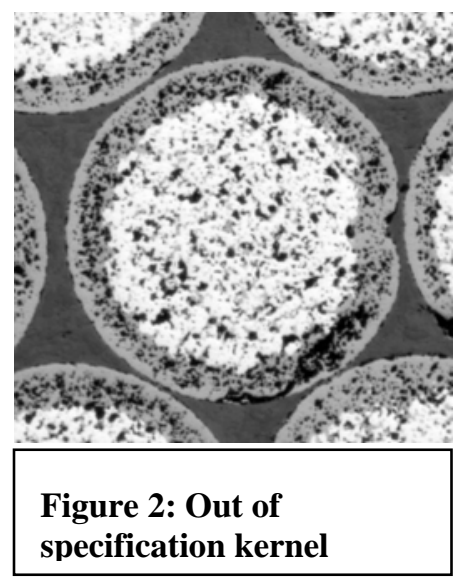
1.15. Thus, we fell back to the $10 \%$ population fraction beyond the critical limit value used for the NP-MHTGR target particles (which were the same size as AGR fuel particles). However, adopting a critical limit of 1.15 was problematic because it would allow grossly deformed kernels to be accepted. Thus, the 1.05 value of aspect ratio was retained as the critical limit.

\subsubsection{Table 4.1 Ceramography}

The "Comments" for the ceramography test was clarified to eliminate the strict requirement of determining the presence of $\mathrm{UO}_{2}$ and $\mathrm{UC}_{2}$ phases. The ceramographer does not have chemical analytical capability in an optical microscope, so it is not feasible to positively identify the phase compositions being viewed beyond identification of light (carbon rich) and dark (oxygen rich) phase structures.

\subsubsection{Table 4.2 Process Impurities: $P$ and $S$}

The change in the $\mathrm{P}$ and $\mathrm{S}$ impurity specification resulted from a clarification of the supporting General Atomics GT-MHR and baseline AGR fuel design specifications. Originally, GA included $\mathrm{P}$ and $\mathrm{S}$ in their total impurities specification but excluded them from an individual impurity specification. The revised $\mathrm{P}$ and $\mathrm{S}$ impurity specification is based upon the difference between the total impurity, as specified by GA, and the sum of the individual impurities (which does not include $\mathrm{P}$ and $\mathrm{S}$ ).

\subsubsection{Section 5.2.1 Variant 6 Particle Handling}

A statement was included in Section 5.2.1 that precluded the sieving, or riffle sampling of particles removed from the coater after $\mathrm{SiC}$ coating. It was determined that such special treatment of this variant would eliminate a known characteristic (transition metal contamination of the exterior $\mathrm{SiC}$ surface) that is of interest in the expected irradiation performance for interrupted coating material. Therefore, the statement was reversed to indicate that the $\mathrm{SiC}$-coated material would be handled like fuel particles historically 
manufactured by the interrupted coating process. This includes sieve sorting and riffle splitting to obtain samples for QC testing.

\subsubsection{Table 5.3 Magnification Requirement}

The original magnification requirement of 500X was determined excessive for the feature identifications requested for $\mathrm{SiC}$ coatings. While providing greater resolution, the higher magnification has a much shorter focal length that translates to the need for high intensity light, perfectly flat samples, exceptional quality translating microscope stages, and the need to re-focus continually. A magnification of about $300 \mathrm{X}$ is better and would allow viewing of one fourth of the fuel particle in one field of view. However, since the objective and eyepiece magnifications available for microscopes are not standardized, it was considered necessary to allow a wider range of magnifications. Setting the minimum at 200X was considered sufficient to resolve the defects of interest and should provide the analyst with usable objective and eyepiece combinations for almost any metallurgical microscope.

\subsubsection{Table 5.3 and 5.4 Requirement on Missing OPyC}

Analysis for missing OPyC layers is constrained by the OPyC thickness specification and will be minimized by sieving to remove undersize particles prior to measurement. Making a statistical statement about the number of missing OPyC layers at the desired defect fraction will require analysis of a large number of particles $(30,000$ or more). If a destructive analysis is used it would be very costly and result in a significant portion of each batch lost for defect measurement. A footnote was added to both the batch and composite specification to indicate that this measurement is a nondestructive visual inspection of coated particles to determine the number of uncoated $\mathrm{SiC}$ layers in the sample population (NOTE: The uncoated $\mathrm{SiC}$ layer is a bright reflective gold color which sharply contrasts with the dull black of an OPyC pyrocarbon and is easy to identify visually.)

\subsubsection{Table 5.4 Clarification on SiC Defect Fraction}

The determination of the $\mathrm{SiC}$ defect fraction is a destructive test requiring analysis of a large population of coated particles. Clarification on the approach to be used was thought necessary to avoid confusion about the test. Rather than $\sim 100,000$ separate tests, one sample population of $\sim 100,000$ particles is analyzed in one test that reveals the total uranium leached from the population. This quantity of uranium leached is mathematically related to the number of fuel kernels that were leached, and directly correlates to the number of defective SiC coatings in the sample that allowed leachant access to the fuel kernel.

\subsubsection{Table 5.4 Micro structural Analysis of SiC}

Micro structural analysis was specified, but the tests required to meet the specification requirement were not identified. A note was added to define the intent of the requirement and bound the work to be performed to meet the specification. 


\subsection{REVISION 2 DATED 4/14/05}

Changes to Revision 1 of this specification were made in response to comments from personnel at Oak Ridge National Laboratory, General Atomics and BWXT on Revision 1 , TCT discussions of baseline and variant particles and compact specifications, comments discussed in a meeting at ORNL on February 23, 2005 and follow up comments by email and phone in March and April, 2005.

\subsubsection{Non-normal distributions.}

Historical data will be reviewed to (a) validate the assumption of normal distributions for specified variable properties, and (b) if populations do not prove to be normally distributed, to evaluate the nature of the departure from normality and the impact of such departure on the acceptance test decision.

\subsubsection{Coating process variants.}

Results from kernel development ORNL have shown that replicating German coating properties required process conditions outside the ranges specified in Rev. 1 of this document. Based on these results, a coater run test matrix was defined that will generate the data that will enable selection of the baseline and variant fuels.

\subsubsection{Section 5.1.1 Sieving.}

The requirement was added to use electroform screens. These screens have a tighter tolerance and are available in more sizes than conventional screens. The requirement to sieve all particle batches using sieve sizes of 700 and $850 \mu \mathrm{m}$ was added. The lower sieve size is based on summing the kernel diameter of $365 \mu \mathrm{m}$ (= the mean of $349+2$ times the standard deviation of $8 \mu \mathrm{m}$ ), a buffer thickness of $30 \mu \mathrm{m}$, and IPyC, SiC and $\mathrm{OPyC}$ thicknesses equal to their nominal values plus twice the standard deviation. This sum, $697.6 \mu \mathrm{m}$, was rounded to $700 \mu \mathrm{m}$ to obtain the lower screen size. A buffer thickness of $30 \mu \mathrm{m}$ corresponds to a failure fraction of about $4 \times 10^{-5}$. The larger screen size was obtained by doing the same calculation with a buffer thickness of $110 \mu \mathrm{m}$, and rounding down from 858 to $850 \mu \mathrm{m}$.

\subsubsection{Section 5.1.2 Tabling.}

The calibration specification of the table was deleted as this requirement is implied in the particle aspect ratio specification.

\subsubsection{Section 5.3 Two-out-of-three approach to acceptance of particle batches.} The approach outlined for retested particle batches should a first test show failure was determined not to be acceptable and was therefore deleted.

\footnotetext{
${ }^{\mathrm{e}}$ From Figure A-1, Appendix "Determination of Performance-Based Critical Limits for AGR Preliminary Fuel Specification,” D. Petti et. al., EDF-4198, Preliminary AGR Fuel Specification, April 1, 2004.
} 


\subsubsection{Tables 4.1 and 4.2, Kernel Specifications.}

"Bulk density" was changed to "Envelope density" to be consistent with ASTM D3766 definitions for density.

In Table 4.2 a new specification, the carbon plus oxygen to uranium ratio, was added. Specifying this ratio to $\leq 2.0$ constrains the kernel composition to contain no free carbon.

The footnote shown for the surface area specification in Table 4.2 did not apply and was deleted.

The kernel density specification was changed from $10.4 \mathrm{~g} / \mathrm{cm}^{3}$ to $10.3 \mathrm{~g} / \mathrm{cm}^{3}$ for batches and from $10.5 \mathrm{~g} / \mathrm{cm}^{3}$ to $10.4 \mathrm{~g} / \mathrm{cm}^{3}$ for kernel composites. In late 2004 , using natural uranium feed, BWXT demonstrated the ability to repeatably produce kernels with densities of $10.5-10.7 \mathrm{~g} / \mathrm{cm}^{3}$. However, because of the uncertainty at this time in the standard deviation of kernel density measurements by mercury pycnometry, an excessively large number of samples $(\sim 20-100)$ would be needed to have high confidence of not rejecting a kernel batch or composite that in reality had a density $>10.5 \mathrm{~g} / \mathrm{cm}^{3}$ (for a composite). Reducing the kernel density specification by $0.1 \mathrm{~g} / \mathrm{cm}^{3}$ allows for a more reasonable sample size ( 3 for kernel batches and 5 for composites). While test run data would indicate that actual densities will still exceed $10.5 \mathrm{~g} / \mathrm{cm}^{3}$, the reduction of the composite specification to $10.4 \mathrm{~g} / \mathrm{cm}^{3}$ is equivalent to a reduction of $1 \%$ in density.

\subsubsection{Table 5.3, Particle Batch Specifications.}

The $\mathrm{SiC}$ thickness was corrected from $36 \pm 4$ microns to $35 \pm 4$ microns.

The SiC gold spot specification was moved from Table 5.3 to Table 5.4 because of recognized difficulties demonstrating the absence of gold spots without consuming a high fraction of the particle batch.

It was recognized that satisfying a value of "none" for missing OPyC layers was impossible, and hence numeric values were provided for this specification. The value was set at twice the values for the same specifications in the particle composite, to allow for batch-to-batch variability and not discard batches that, when blended with other batches, would result in an acceptable composite. However, this batch specification was retained in order to minimize the risk of generating composites that would not meet the composite specifications.

The missing buffer layer specification was moved from Table 5.3 to Section 5.1.1, Sieving, because the specification of missing buffers is satisfied by sieving the particles.

\subsubsection{Table 5.4, Particle Composite Specifications.}

Coating variants will be selected based on characterization of particles that include those from a matrix of coater runs at different IPyC coating gas fractions. The coating gas 
fraction affects the IPyC coating rate. From historical studies, it has been established that anisotropy increases with decreasing coating rate and layer density increases with increasing coating rate. It is expected that variants will be selected with densities within the specified region, but not necessarily within the specified anisotropy region. Thus, a note was added in Table 5.4 stating that the anisotropy specification does not apply to variants produced by coating conditions, purposely varied, that affect anisotropy.

Footnote (c) was deleted from the $\mathrm{SiC}$ and $\mathrm{OPyC}$ density specifications. $\mathrm{SiC}$ and $\mathrm{OPyC}$ densities will be obtained on fully coated particles. SiC density will be obtained by $\mathrm{SiC}$ shards using the gradient column method and OPyC density by either the same method or a weight/volume based method. A footnote was added to clarify that the specification values of IPyC and OPyC densities correspond to those measured by the sink/float method, and if any other method is used, a correlation must be developed to relate the densities to the specification values.

Several updates were made in Table 5.4 to make these specifications consistent with Revision 1 of the Preliminary AGR Fuel Specification, EDF-4198. A footnote was added to specify measuring $\mathrm{BAF}_{\mathrm{o}}$ of the IPyC and OPyC layers prior to compacting. Also the IPyC and OPyC anisotropy critical limit was changed to $\geq 1.06$.

The SiC gold spot defect fraction was moved from Table 5.3 to Table 5.4, consistent with EDF-4198. Visible standards were added to discriminate between particles with gold spots that should be counted as such relative to this specification and particles with gold spots that are too small to be of concern.

Visual standards were added for evaluating the $\mathrm{SiC}$ microstructure specification of Table 5.4 What is desired in $\mathrm{SiC}$ microstructure is to replicate that of German particles, and these microphotograph standards depict both the target and unacceptable SiC microstructure.

The missing buffer fraction specification was deleted, as sieving all the batches that make up the particle composite will satisfy this specification.

IPyC and OPyC microstructure, shown in Rev. 1 as "measurement only" with no numeric specifications, were moved to Table 5.5, as this table is more appropriate for desired particle characterization information beyond specified properties.

Appendix A provides a basis for the fuel defect fraction specifications. The discussion in Appendix A specifies "about 100,000 particles" to be used to determine the SiC defect fraction of particles in a composite. Further analysis has shown that at a sample size of 50,000 particles, at most one defect is allowed for the specification to be met at $95 \%$ confidence, while a sample size of 120,000 particles would allow up to 6 defects, and a sample of 220,000 particles up to 13 defects at the same confidence level. The recommendation of Appendix A has not changed, but the footnote on the $\mathrm{SiC}$ defect fraction in Table 5.4 was deleted to allow for a smaller sample size should development 
data demonstrate that the specification could be met with $95 \%$ confidence and a smaller sample size.

\subsubsection{Table 5.5, Additional Particle Characterization.}

A comment was added to "IPyC permeability" to explain how this property will be measured. Also, the units shown for IPyC permeability were deleted.

IPyC and OPyC anisotropy were deleted from this table, as these properties are specifications shown in Table 5.4. Also, SiC gold spots measurement was deleted from this table, as it is shown as a specification in Table 5.4.

The comment regarding measuring IPyC and OPyC crystallite size were changed from "TEM" to "X-ray diffraction or other suitable method." The microstructure will be evaluated using TEM, but to determine crystallite size, X-ray diffraction is usually used. Microstructure evaluations were moved from Table 5.4 to Table 5.5.

The IPyC and OPyC surface connected porosity specification of $1.3 \mathrm{ml} / \mathrm{m}^{2}$ was made a lower limit, with the upper limit TBD. This is consistent with EDF-4198. Also, the definition of surface connected porosity, as given in footnote (b) was clarified.

The measurement of the SiC-IPyC interface was added as this property reflects a significant difference between German particles and history US particles. The OPyC envelope density by mercury pycnometry was added as this property, along with the OPyC surface connected porosity, will provide information about the layer pore structure that could be important in understanding particle performance.

\subsubsection{Table 6.2, Compact Specifications.}

The uranium homogeneity specification was deleted, as no requirements have been identified for this parameter. However, during development of the compacting process, uranium homogeneity should be measured to confirm distribution of particles in the compact is reasonably uniform and that no specification is needed.

For the uranium loading specification, the "Fraction outside limit" was changed from a fraction of 0.01 to "not specified'. Without critical limits on this specification, the fraction outside the limits is meaningless. For ATR-1, critical limits on the uranium loading are not required; for other AGR fuel specifications, critical limits for this parameter should be considered.

The uranium loading specification was changed from $0.945 \pm 0.015 \mathrm{~g}$ uranium per compact to $0.905 \pm 0.04 \mathrm{~g}$ uranium per compact. The new specification value is based on a kernel uranium content of 90 weight percent, a kernel density of $10.5 \mathrm{~g} / \mathrm{cm}^{3}$, a kernel diameter of $350 \mu \mathrm{m}$, a particles diameter of $780 \mu \mathrm{m}$, mean compact dimensions of 1.234 $\mathrm{cm}$ diameter by $2.54 \mathrm{~cm}$ length, and a packing fraction of $34.9 \%$. The tolerance is based on the allowable variation in compact size, equivalent to about $\pm 0.025 \mathrm{~g}$ uranium per 
compact, plus additional allowances for uncertainty in overcoating thickness (or number of particles per compact) and deviations in kernel properties and coating thicknesses.

The compact diameter specification was changed from a mean with a tolerance to no specified mean but upper and lower critical limits equivalent to the same range as the mean with the tolerance allowed. No compacts outside these critical limits are now allowed. While good control of compact diameter in the compacting process is expected, this change avoids the possibility of accepting compacts that have a wide diameter variation.

Similarly the compact length mean specification was deleted and critical limits, with none allowed outside the critical limits, were added. The upper critical limit of $25.4 \mathrm{~mm}$ ensures that the experiment stack height limitation is satisfied. The experiment designer provided a tolerance on the compact length of $+0 /-0.38 \mathrm{~mm}$. However, the lower critical limit was set at $25.21 \mathrm{~mm}$, half of the allowable total tolerance, based on compacting experience to date that indicates a very tight length is achievable and the objective to closely approach the target length of $25.4 \mathrm{~mm}$.

The heavy metal contamination specification was increased from $\leq 5 \times 10^{-5}$ to $\leq 1 \times 10^{-4}$. Heavy metal contamination includes tramp uranium, i.e, finely dispersed uranium on the surface of particles and in the matrix, and uranium from exposed kernels. Historically the tramp uranium has been well below the specification. The revised specification is equivalent to one exposed kernel in 10,000 particles, the number of particles in about 2.4 compacts. Increasing the specification to $1 \times 10^{-4}$ makes the heavy metal contamination specification consistent with the defective SiC fraction for particle batches. While the increase in the specification could potentially raise the background level during irradiation, calculations verified that monitoring could adequately detect individual particle failures.

Previously numbered footnotes (b), relating to compact length, and (c), relating to compact strength, were deleted. Critical limits were added to the compact length specification, making footnote (b) unnecessary. Footnote (c) was incorrect.

The compact crush strength was changed from an attribute to variable property. If treated as an attribute with a specified defect fraction limit of 0.05 , no less than 60 compacts would have to be crushed (with no defects observed) in order to show conformance to the specification. Because this is excessive, it was changed to a variable property. The sample size needs to be evaluated during compacting development.

The chlorine specification was made applicable only if the compacts are subjected to $\mathrm{HCl}$ cleaning. The purpose of this specification historically has been to ensure that $\mathrm{HCl}$ is adequately removed after $\mathrm{HCl}$ cleaning. If $\mathrm{HCl}$ cleaning is not performed, the specification is not required.

The specifications for impurities $\mathrm{Cr}, \mathrm{Mn}, \mathrm{Co}$ and $\mathrm{Ni}$, and for $\mathrm{Ti}+\mathrm{V}$ were converted to units consistent with the other metal impurity specifications. All of these impurities can 
be measured by ICP analysis of leach solutions from the leach-burn-leach test. Hence specification shows units of $\mu \mathrm{g}$ of impurity outside the $\mathrm{SiC}$ layer per compact.

Calculations to convert concentrations of $\mathrm{Ti}+\mathrm{V}$ from ppm to $\mu \mathrm{g}$ of impurity outside the $\mathrm{SiC}$ layer are shown below:

$$
\begin{aligned}
& \text { Volume of compact }=(\pi / 4) *\left(D^{2} * \mathrm{~L}\right)=(\pi / 4) *(12.34 \mathrm{E}-3 \mathrm{~m})^{2} * 25.4 \mathrm{E}-3 \mathrm{~m}= \\
& 3.03776 \mathrm{E}-6 \mathrm{~m}^{3}=3.03776 \mathrm{~cm}^{3} \\
& \text { Volume OPyC layer }=(4 \pi / 3) *\left\{[(175+100+40+35+40) / 10000]^{3}-\right. \\
& \left.[(175+100+40+35) / 1000]^{3}\right\}=6.888 \mathrm{E}-05 \mathrm{~cm}^{3} \\
& \text { Volume of OPyC in compact }=6.888 \mathrm{E}-05 * 4279=0.29474 \mathrm{~cm}^{3} \\
& \text { Mass outside } \mathrm{SiC} \text { layer }= \\
& \text { (1-packing fraction }) * \rho_{\text {matrix }} * \mathrm{~V}_{\text {compact }}+\rho_{(\mathrm{OPyC})} * \mathrm{~V}_{\mathrm{OPyC}}= \\
& 0.65 * 1.75 * 3.03776+1.9 * 0.29474=4.01546 \mathrm{~g}
\end{aligned}
$$

Original $\mathrm{Ti}+\mathrm{V}$ specification: 100 wt ppm outside $\mathrm{SiC}$ layer

100 ppm converted to $\mu \mathrm{g}$ per compact outside SiC layer: $100 * 4.01546=$ $401.5 \mu \mathrm{g}$

\section{Round to $400 \mu \mathrm{Hg} \mathbf{T}+\mathrm{V}$ outside SiC layer per compact}

The revised specification for transition metals was based on maintaining consistency between the historical specifications for $\mathrm{Fe}$ and the other transition metals. In preparing the GT-MHR fuel product specification, General Atomics changed the Fe specification from $\leq 20$ micrograms Fe/gram burned-back particles to $\leq 50$ micrograms. This effectively lowered the Fe limit for all but the most lightly loaded compacts. However, the specification for the other transition metals was kept at $\leq 55 \mathrm{ppm}$ in the GT-MHR spec (although it was later recommended lowered to $50 \mathrm{ppm}$ for AGR fuel compacts). The old HTGR specification of $\leq 20$ micrograms Fe/gram burned-back particles would be equivalent to a specification of $\leq 46$ micrograms for the AGR-1 compacts. Thus the specification for Fe has been reduced by about $50 \%$ relative to the old HTGR specification, but the specification for the other transition metals has only been reduced by about $10 \%$.

A further consideration is the large difference in the density of the AGR-1 thermosetting matrix (about $1.75 \mathrm{~g} / \mathrm{cc}$ ) vs. thermoplastic matrix (about $0.8 \mathrm{~g} / \mathrm{cc}$ ). For the same particles and packing fraction, the weight of a compact fabricated with the thermoplastic matrix historically used for US HTGRs would be about 4.46 grams (vs. 6.34 grams for a compact made with thermosetting matrix). Based on this compact weight, the specification for $\mathrm{Ni}, \mathrm{Cr}, \mathrm{Co}$, and $\mathrm{Mn}$ would compute to be 122 micrograms. 
Given the above considerations, the specification for $\mathrm{Ni}, \mathrm{Cr}, \mathrm{Co}$, and $\mathrm{Mn}$ is changed to [122 micrograms $\times(25 / 46) \times(55 / 50)]=72.9$ micrograms, rounded to 75 micrograms each transition metal outside $\mathrm{SiC}$ layer per compact.

\subsubsection{Appendix A clarifications and changes:}

Section 5 of Revision 1 of Appendix A was deleted to avoid confusion about 50\% confidence specifications. Footnotes (a) and (b) of the first table were clarified by changing "particle composite mean defect fraction" to "particle composite defect fraction." The figure was clarified by labeling the legend and adding a figure title. Titles were also added to the tables in Appendix A.

A footnote in Section 2 was added to explain that the particle batch size, originally assumed to be $100 \mathrm{~g}$, is now more likely to be $60-70 \mathrm{~g}$.

The heavy metal contamination specification in Tables A-1 and A-3 was changed to be consistent with the change of this specification made in Table 6.2.

Based on analysis and recommendations of the TCT, the recommendation to use at least 100,000 particles to measure defect fractions was qualified to allow meeting this requirement through pooling of data.

\subsubsection{Revision 2 Summary}

Changes to Revision 1 of the AGR-1 Specification were made in response to comments received from personnel at Oak Ridge National Laboratory, General Atomics, and BWXT, changes discussed at a meeting of the Technical Coordination Team (TCT) in December 2004, follow-on discussions by the TCT of compact specifications, discussions regarding the specification in a meeting at ORNL on February 23, 2005 and follow up comments in March and April 2005. The changes are as follows:

- A review of historical data and other relevant documents will be made to validate the assumption of normal distributions of specification properties and evaluate departures from normality.

- The process parameter-based approach to particle variants was replaced with a property-based approach and selection of variants by the Technical Coordination Team based on results of coater studies. A brief discussion of how process parameters affect layer properties was added as an Appendix.

- A new specification, the carbon plus oxygen to uranium ratio, was added for kernel composites (Table 4.2).

- The kernel density specification was changed from 10.4 to $10.3 \mathrm{~g} / \mathrm{cm}^{3}$ for batches and from 10.5 to $10.4 \mathrm{~g} / \mathrm{cm}^{3}$ for composites (Table 4.2).

- The option to retest particle batches that fail the first test was deleted.

- The SiC layer thickness was corrected in Table 5.3.

- The SiC gold spot specification previous shown in Table 5.3 (particle batches) was moved to Table 5.4 (particle composites) and visual standards were added for evaluating gold spots. A footnote defining gold spots was also added.

- Numerical limits were added for missing IPyC layers in Table 5.3.

- The critical limit for IPyC and OPyC anisotropy was changed to 1.06 (Table 5.4).

- A comment was added in Table 5.4 to clarify that the IPyC anisotropy specification does not apply to variants with purposely altered IPyC anisotropy.

- Visual standards were added for evaluating the $\mathrm{SiC}$ microstructure specification of Table 5.4, and a footnote added stating that 3 particles will be examined to determine $\mathrm{SiC}$ microstructure. 
- A footnote was added to Table 5.4 to indicate that $\mathrm{BAF}_{\mathrm{o}}$ is to be measured before compacting.

- A footnote to IPyC and OPyC density specifications in Table 5.4 was added to indicate that the specification values correspond to densities measured by the sink/float method.

- IPyC and OPyC microstructure were moved from Table 5.4 (particle composite requirements) to Table 5.5 (desired additional characterization).

- The units of IPyC permeability were deleted and a comment added that permeability would be determined using 18 -hour chorine leach at $1500^{\circ} \mathrm{C}$.

- The footnote specifying that $\sim 100,000$ particles were needed for measuring $\mathrm{SiC}$ defect fraction (Table 5.4) in the coated particles was deleted.

- A footnote was added to Table 6.1 indicating compacting process conditions were subject to revision based on results of development tests.

- Critical limits were added to the compacting diameter specification in Table 6.2 and the mean diameter specification deleted.

- Critical limits on the compact length specification were added in Table 6.2 and the mean compact length specification deleted.

- The uranium loading compact specification (Table 6.2) was changed from $0.945 \pm 0.015 \mathrm{~g} \mathrm{U}$ per compact to $0.905 \pm 0.04 \mathrm{~g} \mathrm{U}$ per compact.

- The uranium homogeneity specification for compacts was deleted from Table 6.2.

- The specifications for compact impurity specifications for $\mathrm{Cr}, \mathrm{Mn}, \mathrm{Co}$ and $\mathrm{Ni}$, and $\mathrm{Ti}+\mathrm{V}$ were converted to units of $\mu \mathrm{g}$ per compact outside $\mathrm{SiC}$ layer to be consistent with the units of other compact impurity specifications. Also the transition metal impurity specification was reviewed against historical specifications and adjusted.

- The compact crush strength was changed from an attribute to a variable property.

- The assumptions implied in the uranium loading specification in Table 6.2 were stated.

- The heavy metal contamination specification of Table 6.2 was changed from $5 \times 10^{-5}$ to $1 \times 10^{-4}$.

- A footnote was added to the compact chlorine specification (Table 6.2) saying that the specification only applies if the compacts are $\mathrm{HCl}$ leached.

- A definition of defective OPyC particles was added as a footnote to the defective OPyC specification of Table 6.2.

- That the missing buffer specification was satisfied by sieving was clarified by deleting this specification from Tables 5.3 and 5.4 and changing Section 5.1.1 to specify sieving of every batch by electroform sieves of $700 \mu \mathrm{m}$ and $850 \mu \mathrm{m}$.

- The requirement formerly in Section 5.1.2 (tabling) regarding calibration of the table to reject particles of a given aspect ratio was deleted.

- A measurement characterizing SiC-IPyC bonding was added to Table 5.5 as desired additional particle characterization.

- The OPyC envelope density was added to Table 5.5 as desired additional particle characterization.

- The footnote of Table 5.5 that mean values and fractions in critical regions were required to be determined at the $95 \%$ confidence level was deleted.

The process conditions for coating AGR-1 baseline and fuel variants are not final at this time and will be added in the next revision of this specification.

\subsection{REVISION 3 DATED 8/31/05}

\subsubsection{Baseline and variant particle}

Process conditions for the baseline and variant particles were determined based on results of ORNL parametric studies. The basis for the selection of these conditions is documented in the Notes of the Technical Coordination Team (TCT) Meeting held on May 10, 2005 at ORNL. 
The TCT recommendation of some coating temperatures were not exact but allowed for small changes to better meet specification properties. The tolerance of $\pm 10^{\circ} \mathrm{C}$ for IPyC, $\mathrm{SiC}$ and OPyC temperatures is half of that shown in Rev. 1 of this specification, and was reduced to more closely replicate desired properties achieved in the IPyC parametric study. No tolerance was specified for the buffer coating because of the exothermic nature of this coating. Tolerances on coating gas fractions were taken from EDF-4198 Rev. 1, Table 4-1.

\subsubsection{Table 5.4, Particle Composite Specifications}

The original aspect ratio specification for particle composites was based upon performance-based calculations using data available prior to September 2003. Later results from the ORNL coating development and particle characterization effort have prompted a re-evaluation of this specification.

The original performance-based upper critical limit for particle aspect ratio was determined based upon an assumed mean aspect ratio of 1.014. This mean value was derived by uniformly propagating the sphericity of a $350 \mu \mathrm{m}$ diameter kernel with an aspect ratio of 1.030 to a particle diameter of $780 \mu \mathrm{m}$. While the kernel aspect ratio value is realistic (the same as characterized by ORNL for the NUCO kernels from BWXT 69300 Composite), the resulting mean coated particle aspect ratio may be considered unrealistically small when compared to recent ORNL characterization data for comparable size particles as listed in the table below.

ORNL Fuel Characterization Data

\begin{tabular}{|l|l|l|l|}
\hline Particle & $\begin{array}{l}\text { Mean Diameter } \\
(\mu \mathrm{m})\end{array}$ & Mean Aspect Ratio & $\begin{array}{l}\text { Aspect Ratio } \\
\text { Standard Deviation }\end{array}$ \\
\hline $\begin{array}{l}\text { HRB-21 Reference } \\
\text { Fuel }\end{array}$ & 798 & 1.07 & 0.02 \\
\hline $\begin{array}{l}\text { NUCO350-28B } \\
\text { multi-inlet coater }\end{array}$ & 766 & 1.042 & 0.014 \\
\hline $\begin{array}{l}\text { NUCO350-28/34B } \\
\text { multi-inlet coater }\end{array}$ & 814 & 1.047 & 0.017 \\
\hline $\begin{array}{l}\text { NUCO350-51-1A } \\
\text { single inlet coater }\end{array}$ & 808 & 1.057 & 0.021 \\
\hline
\end{tabular}

Considering the large difference between the recent characterization data and the originally assumed mean aspect ratio value, the performance-based critical limit evaluation (using the method described in the Preliminary AGR Fuel Specification) was extended to cover a range of mean aspect ratios (up to 1.24). The results are summarized in the following figure where cumulative failure fractions are plotted as a function of the upper $1 \%$ critical limit for various aspect ratio standard deviations. The $1 \%$ critical limits can be converted to mean aspect ratios by the following relation:

mean aspect ratio $=1 \%$ critical limit -2.326 (aspect ratio standard deviation). 
Considering current fabrication capabilities where particle aspect ratio standard deviations vary about 0.02 and selecting a cumulative failure fraction of approximately less than $10^{-6}$, the AGR-1 particle sphericity specification was changed to $\leq 1 \%$ of the particles shall have an aspect ratio $\geq 1.14$.

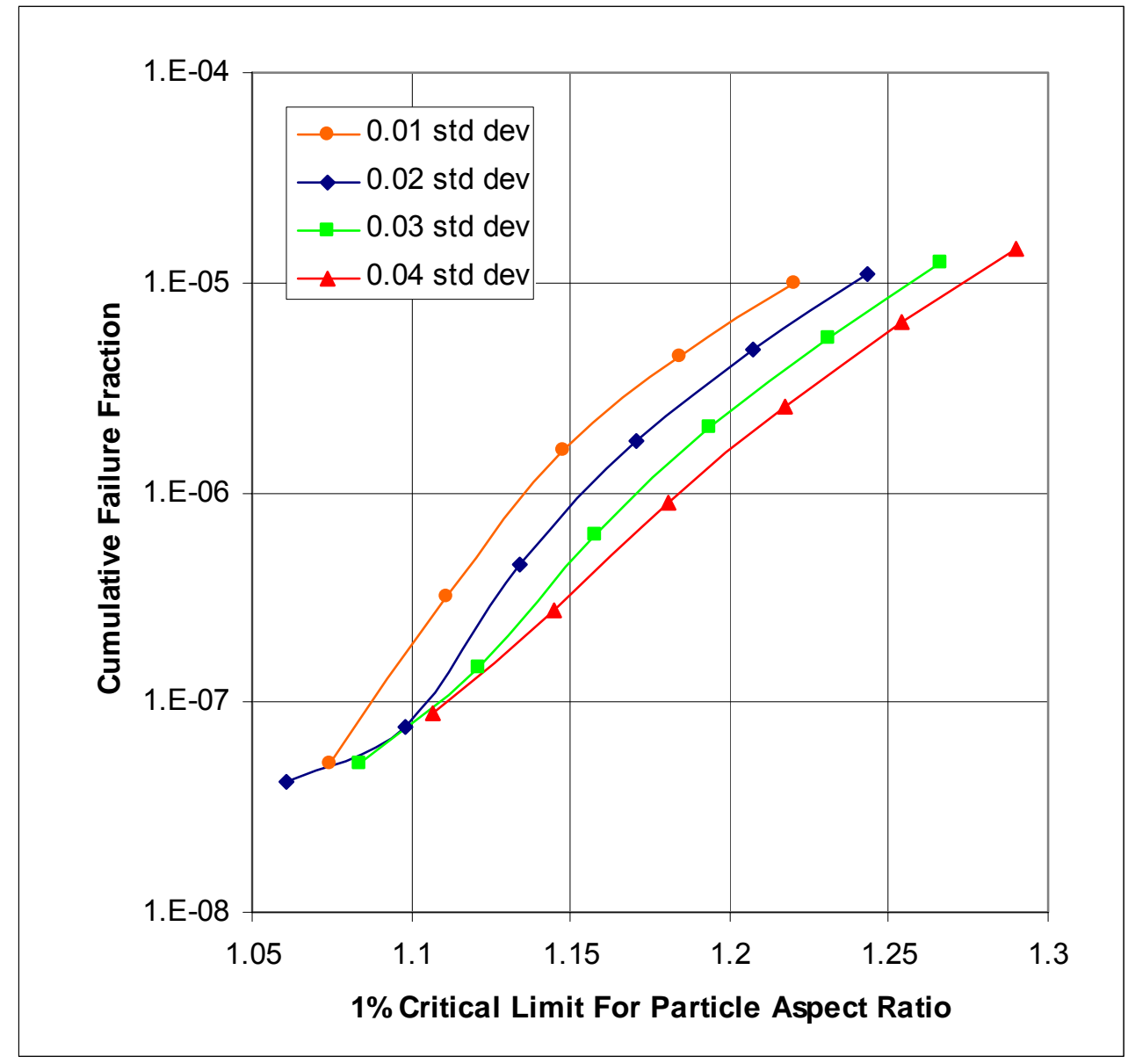

During $\mathrm{SiC}$ coating, a reaction between the kernel and buffer coating occurs leaving a $\mathrm{UC}_{2}$ shell between the kernel and buffer layer. Calculations indicate that this shell could extend as much as 9 microns into the buffer layer. Images of mounted particles indicate that the thickness of this layer could be as much as 15 microns, however the extent that it replaces original kernel volume is not known. Because of the uncertainty in the effect on buffer thickness of this $\mathrm{UC}_{2}$ layer, the tolerance on the buffer thickness was increased to 15 microns.

The buffer density specification was changed to $1.05 \pm 0.20 \mathrm{~g} / \mathrm{cm}^{3}$ from $0.95 \pm 0.15 \mathrm{~g} / \mathrm{cm}^{3}$. Coating runs at ORNL showed that when the buffer temperature is raised to get a density below about $1.0 \mathrm{~g} / \mathrm{cm}^{3}$, volcano-shaped soot deposits in the bottom section of the cone. The higher the temperature, the greater the deposit, and the larger the "volcano". The larger the volcano, the more particles that get trapped in the bottom of the cone. To 
eliminate the volcano, ORNL dropped the temperature to $1350^{\circ} \mathrm{C}$. Buffer densities at this temperature were in the range of 1.07 to $1.2 \mathrm{~g} / \mathrm{cm}^{3}$.

Low density is needed in the buffer layer to provide void volume for fission product gases and control the internal pressure of the particle during irradiation. The revised specification still provides ample void volume. At the high end of this specification, 1.25 $\mathrm{g} / \mathrm{cm}^{3}$, the buffer layer would have a void volume of $76 \%$ of that for a particle with the nominal buffer thickness of 100 microns and the previous nominal density of 0.95 . Or looking at it another way, a particle with a density of $1.25 \mathrm{~g} / \mathrm{cm}^{3}$ and the nominal thickness of 100 microns would have the same void volume as one with a thickness of about 83 microns and a density of $0.95 \mathrm{~g} / \mathrm{cm}^{3}$. A particle with a buffer thickness of 85 microns, the lower limit of the mean specification, and a density at the upper limit, 1.25 $\mathrm{g} / \mathrm{cm}^{3}$ would have the minimum void volume allowable by the specifications. This void volume would be equivalent to that for particles with the previous mean density, 0.95 $\mathrm{g} / \mathrm{cm}^{3}$, and a thickness of about 70 microns. From Figure A-1 in EDF-4198, the expected failure fraction changes very little, and is less than $10 \mathrm{E}-7$, for all buffer thicknesses above 50 microns.

\subsubsection{Table 6.1, Compacting Process Limits}

Compacting heat treatment conditions were changed based on compact process development information. The compact heat treatment temperature was discussed in the June 15 AGR Program teleconference, with the recommendation to use $1800^{\circ} \mathrm{C}$. The range for this temperature was not changed from previous revisions of this specification or the Preliminary AGR Fuel Specification, EDF-4198, Rev. 1.

\subsubsection{Table 6.2, Compact Specifications}

Data supplied by Pete Pappano from compacts made during development show a range of length in heat-treated compacts of $0.21 \mathrm{~mm}$ for nine compacts treated at $1400^{\circ} \mathrm{C}$ and 0.86 $\mathrm{mm}$ for the same number treated at $1800^{\circ} \mathrm{C}$. The corresponding standard deviations for these sets of data are 0.074 and $0.254 \mathrm{~mm}$ respectively. Based on these data and the acceptability from a capsule design standpoint of shorter compacts, the lower critical limit was reduced from 25.21 to $25.02 \mathrm{~mm}$.

Compact diameter measurements are needed for each compact that could go into the capsule (fuel plus spares) to perform final irradiation test predictions and capsule design. A footnote was added specifying the number of diameter measurements and locations needed for each compact.

The compact visual standard specification was deleted as ORNL compact development data has shown that it is not needed. The visual standard for compact integrity is of a compact made by a different compacting process, in which the particles and filler are poured into the mold and then pitch is injected into the mold. In this process particles could be forced to the sides of the compact and be exposed after the compact is ejected 
from the mold. The visual standard shows pictorial evidence of this, with exposed particles. However in the AGR compacting process, the matrix overcoating process ensures that the matrix is the perimeter of the compact, not a particle. The overcoated particles are poured into a mold and then pressed. The compacts have prepressed endcaps.. Also, the particle loading of $35 \%$ is less than the $60 \%$ used for the compact shown in the visual standard. For these reasons, plus visual observations of all compacts produced to date, there is virtually no chance for exposure of particles on the compact surfaces.

\subsubsection{Table 5.2, Particle Composite Specifications}

The visual standards for the "target" and "too small" SiC microstructure were deleted and the specification reworded to be less than the average size shown on the remaining "too large" images. The basis for this change was a series of coating runs performed at ORNL. The images from these runs show a systematic increase in grain size with increasing temperature. The lower grain size limit is not needed because the specification on the density would cover the situation where a small grain size is accompanied by porosity and/or free silicon. Elimination of the "target" standards reduces the subjectivity of the specification, as now the comparison is against (grain size less than) a single standard rather than "closer to" a target size.

\subsubsection{Revision 3 Summary}

Coating conditions for the baseline and variant fuels have been added in Revision 3. Other changes include:

1. The particle aspect ratio critical limit was changed from 1.084 to 1.14.

2. The buffer thickness tolerance was changed from 10 microns to 15 microns for particle composites.

3. The lower critical limit of the compact length was changed to $25.02 \mathrm{~mm}$.

4. A footnote on the compact diameter was added specifying that the compact diameter shall be measured at approximately the top, middle and bottom of each compact at 0 and 90 degrees.

5. Some of the conditions for the final heat treatment in compacting were changed based on compact development results.

6. The section on sorting requirements for variants fuels produced in interrupted runs was deleted.

7. The specification on the density of the buffer layer of coated particles was changed to $1.05 \pm 0.20 \mathrm{~g} / \mathrm{cm}^{3}$.

8. The compact integrity specification and crush strength specification were deleted.

9. Visual standards for $\mathrm{SiC}$ microstructure were updated. 


\subsection{REVISION 4 DATED 11/8/05}

\subsubsection{Table 3.1, Baseline Fuel Conditions}

The baseline fuel conditions shown in Table 3.1 of Revision 3 of this specification were determined based on results of the IPyC deposition study. ${ }^{f}$ It was later found that densities of the buffer layer for runs made for the IPyC deposition study were in the range of $1.2-1.3 \mathrm{~g} / \mathrm{cm}^{3}$. While the buffer density specification was increased to $1.05 \pm 0.20$ $\mathrm{g} / \mathrm{cm}^{3}$ in Revision 3 of this fuel specification based on a review of the requirements for buffer density, additional development runs were needed to better determine buffer and pyrocarbon coating temperatures. The goals of these runs included ensuring a sufficiently low buffer density and avoiding laminar defects in the silicon carbide layer. To allow for flexibility to achieve specification properties while maintaining IPyC permeability and surface connected porosity previously close to what is desired (and used to guide the previous selection of baseline coating conditions), process conditions shown in Table 3.1 were changed, including:

(a) the buffer, IPyC and OPyC coating temperatures

(b) a tolerance of $\pm 25^{\circ} \mathrm{C}$ was added for buffer temperature

(c) the tolerance on the IPyC and $\mathrm{SiC}$ temperatures was increased to $\pm 25^{\circ} \mathrm{C}$,

(d) the tolerance on the $\mathrm{OPyC}$ temperature was increased to $\pm 40^{\circ} \mathrm{C}$, and

(e) the footnote that triggered review by the TCT should deviations in layer density or coating rate exceed specified ranges was deleted.

The revised process temperatures, with the exception of the OPyC temperature, are the same as documented in a June $30^{\text {th }}$ ORNL letter. ${ }^{\mathrm{g}}$ The revised baseline coating conditions were discussed several TCT conference calls in September to early November 2005, and agreed to in a TCT call November 1, 2005, pending confirmation of expected properties of particles made at the revised process conditions. These additional runs include (1) a complete TRISO run made November 1 with LEUCO kernels to verify (a) acceptable levels of bright field and dark field anomalies in the SiC layer, (b) SiC gold spots within the specification, (c) SiC grain size meeting specification, and (4) evidence of strong bonding between the IPyC and $\mathrm{SiC}$ and (2) subsequent interrupted runs with LEUCO kernels to confirm or requalify buffer and IPyC densities.

\subsubsection{Section 3.2 and Table 3.2, Variant Process Conditions}

Conditions for variant particles were put on hold pending determining final conditions for the baseline fuel.

\footnotetext{
${ }^{\mathrm{f}}$ See TCT Meeting Summary for meeting held at ORNL May 10, 2005, dated May 13, 2005 and D.A. Petti letter to Distribution, Baseline and Variant Processing Conditions for Advanced Gas Reactor, CCN 201231, dated June 1, 2005.

${ }^{\mathrm{g}}$ Gary L. Bell, Notification of Completion of Deliverable. "AGR Task 3.1.3.1, Complete Coating Baseline Process Development for AGR-1,” AGR-1036, June 30, 2005.
} 


\subsubsection{Section 5.1.1, Sieving to Remove Undersize and Oversize Particles}

Use of a roller micrometer to remove undersize and oversize particles was added as an alternative to screening. According to Rick Lowden, the advantages of the roller micrometer over screens include:

- The roller micrometer separates particles into 10 fractions; the weight distribution in bins closely matches the size distribution of the particles; hence the roller micrometer can very accurately remove undersize and oversize particles

- The roller micrometer removes small chips and odd shaped particles such that the efficiency of tabling increases dramatically.

- Screens do not take out particles with missing OPyC layers

- Screens are not precise

- Particles stick or get caught in the screens, so that a brush must be used frequently and as a result the particles could be damaged

Analyses of 3 compacts for impurities made with particles separated by the roller micrometer shows that impurity levels are well within specification limits, as shown below. Fred Montgomery reported that the impurities shown below are less than what he has measured for compacts with particles separated by screens.

$\begin{array}{lcc}\text { Specification } & \begin{array}{c}\text { Average of three } \\ \text { compacts (sum of first and } \\ \text { second leach) } \\ \mu g / \text { compact }\end{array} \\ \mathrm{Fe} & \mu \mathrm{g} / \text { compact } & 0 \\ \mathrm{Cr} & \leq 25 & 0 \\ \mathrm{Mn} & \leq 75 & 0 \\ \mathrm{Co} & \leq 75 & 0.4 \\ \mathrm{Ni} & \leq 75 & 21 \\ \mathrm{Ca} & \leq 75 & 13 \\ \mathrm{Al} & \leq 25 & 13 \\ \mathrm{Ti} & \leq 25 & 1 \\ \mathrm{~V} & - & 10 \\ \mathrm{Ti}+\mathrm{V} & - & 11\end{array}$

Based on the above advantages of the roller micrometer and the analysis that shows impurities at acceptable levels, the option to use the roller micrometer to remove oversize and undersize particles was added.

\subsubsection{Section 5.1.2 Tabling to Remove Highly Aspherical Particles}

The requirement to table the particles at least twice was deleted. Tabling once is still required. If, after this tabling, the particles do not meet the aspect ratio specification, retabling is an option and would likely be done. However, based on an increased efficiency of tabling after the particles are separated using the roller micrometer, the requirement to always perform a second tabling was deleted. 


\subsubsection{Section 2 Quality Assurance}

To be consistent with the latest revision of the AGR Program Quality Program Plan (QPP), reference to NQA-1-1997 was deleted relative to fabrication of fuel particles and compacts. However, consistent with Rev. 2 of the INL AGR QPP, in effect at the time of AGR-1 kernel fabrication and consistent with Scope of Work-427 Rev. 5 for fabrication of AGR-1 kernels, it was noted that AGR-1 kernels were produced at BWXT under a quality program which conformed to the requirements of NQA-1 1997.

\subsubsection{Table 5. 2 OPyC Density}

A systematic measurement error in pyrocarbon densities, when particles from a composite sample were measured, was discovered by ORNL. ${ }^{\text {h }}$ It was observed that pyrocarbon densities of a composite were close to the lowest value or even outside the range of densities of the individual batches that made up the composite. It was theorized that the batch to batch variation in density corresponded to differences in microstructure that affected how the particles fractured and resulted in a bias in selecting fragments with lower densities. To ensure accurate $\mathrm{OPyC}$ densities are measured and reported, footnote $\mathrm{j}$ was added to Table 5.2 to specify measurement of OPyC densities from samples of each batch. The composite will be accepted relative to OPyC density if each batch meets the acceptance criteria.

\subsubsection{Table 5. 2 Buffer Density}

In revision 3 , the buffer density was changed to $1.05 \pm 0.2 \mathrm{~g} / \mathrm{cm}^{3}$ based on the analysis in Section 1.4.2. Also the change was initiated based on an anticipated need to apply the buffer layer at a lower temperature, which would produce a higher density. However, additional development runs resulted in the decision to maintain the higher buffer temperature. Also, further evaluation of the buffer density suggests that $\pm 0.2 \mathrm{~g} / \mathrm{cm}^{3}$ is too wide a range. Postirradiation examination of HRB-15A and HRB-16 fuel showed high fractions of buffer failure and kernel extensions into the buffer layer for particles with buffer densities less than about $0.88 \mathrm{~g} / \mathrm{cm}^{3}$. ${ }^{\mathrm{i}}$ Review of NPR data suggests that about $1.2 \mathrm{~g} / \mathrm{cm}^{3}$ is a more appropriate upper limit. Thus the mean density specification was changed to $1.03 \pm 0.15 \mathrm{~g} / \mathrm{cm}^{3}$, reducing the range to 0.88 to $1.18 \mathrm{~g} / \mathrm{cm}^{3}$.

\subsubsection{Table 5.2 Pyrocarbon Anisotropy}

Footnote d was deleted on both the IPyC and OPyC anisotropy. Based on ORNL's diattenuation measurements of IPyC and OPyC layers of a German particle, a method has been determined to relate the diattenuation value to an equivalent $\mathrm{BAF}_{\mathrm{o}}$ value. Hence the footnote is not needed.

\footnotetext{
${ }^{\mathrm{h}}$ AGR Fuel Development and Qualification Program September Monthly Report

${ }^{\text {i }}$ See Table 4-7 of J. W. Ketterer et. al, Capsule HRB-15A Postirradiation Examination Report, GA-A16758, July, 1984 and Table 5-5 of HRB-16 Postirradiation Examination Report, GA Technologies, HTGR-85-053, September 1985.
} 


\subsubsection{Table 5.2 Gold Spot Standard}

The gold spot standard was updated with an image of particles coated at ORNL.

\subsubsection{Compacting Process Limits}

The maximum allowable pressure for forming green compacts was increased to $60 \mathrm{MPa}$ based on compacting development tests that showed that (a) this pressure was needed in certain cases (if a smaller mold is used) and (b) that at this pressure no particles were broken.

\subsubsection{Compact Dimensions}

From the total number of compacts produced, compacts will be randomly selected for destructive analysis. As per footnote (g) of Table 6.2, the length and diameter of all other compacts are to be measured. Based on data from compact development, it is expected that some compacts may not meet the ring test that is used for acceptance of compact diameter. The data has shown that these compacts that fail the ring test, when measured by a caliper, meet the diameter specification, but because of the length of the ring, do not fully pass through. An additional statement was added to footnote (g) to allow compacts that do not meet dimensional specification to be archived.

\subsubsection{Summary of Changes}

Several of the changes made in revision 4 relate to process specifications for baseline and variant particles:

1. The process temperatures for the buffer, IPyC and OPyC layers were changed, and tolerances on all coating temperatures were increased.

2. Footnote 3 of Table 3.1 that triggered review of process conditions by the TCT should densities or coating rates differ from expected ranges was deleted

3. Process conditions for variant particles were put on hold pending additional review by the TCT.

Other changes in revision 4 include (1) defining the acceptance of the particle composite relative to OPyC density specifications by applying the acceptance criteria to samples from each of the batches in the composite, (2) adding use of using a roller micrometer as an alternative to screening to remove undersize and oversize particles, (3) deleting the requirement to table the particles more than once, (4) changing the mean buffer density specification to $1.035 \pm 0.15 \mathrm{~g} / \mathrm{cm}^{3}$, (5) updating the visual standard for gold spots, (6) deleting footnote $\mathrm{d}$ on pyrocarbon anisotropy from Table 5.2 (7) increasing the maximum allowable molding pressure in fabricating green compacts to $60 \mathrm{MPa}(8)$ a footnote was added to specifically allow using compacts not meeting dimension specifications for archive and (9) deleting the reference to the NQA-1 1997 relative to fabrication of particles and compacts.

\subsection{REVISION 5 DATED 12/12/05}

Process conditions for coating two variant fuels are defined in this revision. Conditions for Variants 1 and 2 were discussed by the TCT in a teleconference November 18. The IPyC temperature for Variant 1 will be $1290^{\circ} \mathrm{C}$, with all other specified conditions identical to those for producing baseline particles. This increase in temperature is expected to cause a decrease in density and anisotropy. For Variant 2, the conditions for the baseline will be used except the coating gas fraction will be increased from 0.3 to 0.45 . 
This will result in an increase in coating rate. The basis for the selection of these two variants is given in the minutes of the TCT November 18 teleconference.

No changes other than specifying conditions for variant particles were made in this revision, beyond deleting a footnote reference in Table 3.1 to a footnote that had been previously deleted.

\subsection{REVISION 6 DATED 12/19/05}

Process conditions for coating variant fuels $3 \mathrm{a}$ and $3 \mathrm{~b}$ are defined in this revision. Conditions for these variants were discussed by the TCT in a teleconference on December 15. Variant 3a is to be produced using the baseline fuel conditions except for the $\mathrm{SiC}$ layer. For the $\mathrm{SiC}$ layer, a mixture of argon and hydrogen is to be used as the diluent gas and the temperature reduced from that used for the baseline fuel $\mathrm{SiC}$ deposition. The temperature and argon to hydrogen ratio can be adjusted to meet $\mathrm{SiC}$ microstructure and other specifications. Variant $3 \mathrm{~b}$ is to be produced using the baseline fuel conditions except that after applying the IPyC coating layer, the run is to be interrupted, with the particles discharged, the coater cleaned and the nozzle replaced before applying the final two layers. The basis for the selection of these two variants is given in the minutes of the TCT November 18 teleconference.

No changes other than specifying conditions for Variant particles $3 \mathrm{a}$ and $3 \mathrm{~b}$ were made in this revision.

\subsection{REVISION 7 DATED 2/1/06}

Three changes were made in revision 7. Specifications for allowable levels of $\mathrm{Al}$ and $\mathrm{Ca}$ outside the silicon carbide layer in fuel compacts were increased from $\leq 25 \mu \mathrm{g}$ per compact to $\leq 90 \mu \mathrm{g}$ per compact for $\mathrm{Ca}$ and $\leq 45 \mu \mathrm{g}$ per compact for Al. The allowable fraction of particles with $\mathrm{SiC}$ gold spots was increased from $\leq 1.0 \times 10^{-3}$ to $\leq 5.0 \times 10^{-3}$ for variant 2 and variant 3 a particles. No change in the SiC gold spot specification was made for variant $3 \mathrm{~b}$ particles. The basis for these changes is contained in Deviation requests ORNL-AGR-06-01 and ORNL-AGR-DR-06-02.

\subsection{REVISION 8 DATED 4/21/06}

References to Variant $3 \mathrm{~b}$ were deleted and what previously had been called Variant $3 \mathrm{a}$ was specified as Variant 3, based on the recommendation of the TCT on March 16, 2006 of which coating conditions to use for this variant. 


\section{Appendix C}

\section{Coating Property/Process Relationships}

The ultimate goal of fuel fabrication is the manufacture of ultra-high quality kernels, particles and compacts. ${ }^{1}$ Initial AGR coating development has focused on reproducing particle properties of TRISO-coated particle fuel produced in Germany in the early 1980's. German particles have been characterized by ORNL, ${ }^{2}$ General Atomics, ${ }^{3}$ and Babcock and Wilcox ${ }^{4}$ (now BWXT). Major differences between German and historic US TRISO-coated particles include:

1. The IPyC layer of the German particles is very isotropic, but may have a greater surface porosity than historic US particles.

2. The SiC microstructure of German particles shows smaller, equiaxed grains whereas that of U.S. fuel particles has larger, columnar grains.

3. The IPyC/SiC interface of German particles shows interlacing of $\mathrm{SiC}$ into the pyrocarbon, whereas U.S. particles show a more distinct, smooth interface.

German fuel used a nominal 500- $\mu$ m diameter $\mathrm{UO}_{2}$ kernel. The kernels were coated in 3and $5-\mathrm{kg}$ (as uranium) batches for AVR-21 and -19 campaigns, ${ }^{5}$ increasing to $10-\mathrm{kg}$ batches for later campaigns. ${ }^{16,17} 5-\mathrm{kg}$ batches were coated in a $240-\mathrm{mm}$ diameter coater, while $10-\mathrm{kg}$ batches in a 400-mm diameter coater. ${ }^{19}$ All coating layers were applied without interruption. Quality control was performed on composites. ${ }^{17}$

To more fully determine the relationship between key coated property characteristics and fuel quality, i.e., reactor performance, variant particles will be produced for AGR-1 irradiation tests with (a) different IPyC layer properties and (b) different SiC layer microstructure.

Huschka and Vygen ${ }^{6}$ document typical conditions used in the manufacture of German Fuel TRISO coatings:

\begin{tabular}{|c|c|c|c|}
\hline & Coating Gas & Temperature, ${ }^{\circ} \mathrm{C}$ & Coating rate, $\mu \mathrm{m} / \mathrm{min}$ \\
\hline Buffer & Acetylene & 1250 & $6-10$ \\
\hline IPyC & Acetylene/propylene & 1300 & $4-6$ \\
\hline $\mathrm{SiC}$ & MTS & 1500 & 0.2 \\
\hline OPyC & Acetylene/propylene & 1300 & $4-6$ \\
\hline
\end{tabular}

The exact relationship between most coating properties and coating process parameters is complex and often dependent on coater design as well as operating parameters. Optimum conditions for one coater may not apply to another. However, the major parameters that affect coating properties include the bed temperature, the specific hydrocarbon, the hydrocarbon gas fraction, the gas diluent species, the gas flow rate, the bed surface area, and the volume of the deposition zone. 


\section{$\underline{\text { IPyC anisotropy and permeability }}$}

Pyrocarbon coatings must be very isotropic to survive irradiation. Anisotropic dimensional changes cause high stresses and cracking during irradiation. Permeable IPyC coatings result in attack of the kernel by $\mathrm{HCl}$ during $\mathrm{SiC}$ deposition.

For a given layer thickness, the coating permeability has been shown to be related to porosity and bulk density of the coating. ${ }^{7}$ Low density pyrocarbon layers, less than about $1.85 \mathrm{~g} / \mathrm{cm}^{3}$, tend to be permeable. ${ }^{7}$ Also layers with greater than about $3-4 \%$ open porosity tend to be permeable. ${ }^{7}$ Process variables that affect density and porosity, and hence permeability, include temperature, deposition rate and coater batch size. ${ }^{7,8}$ In one study involving coating with a propylene/acetylene mixture in a $240-\mathrm{mm}$ coater, high density coatings, which were generally gastight, were produced at temperatures in the $1150-1250^{\circ} \mathrm{C}$ range. $^{7}$ In the same study, coating rates below $3 \mu \mathrm{m} / \mathrm{min}$ generally gave gastight particles, while coating rates greater than $4 \mu \mathrm{m} / \mathrm{min}$ gave permeable coatings. ${ }^{7}$ Note that these rates for impermeable coatings are below those used to produce German particles. Also, in this study, increasing the batch size from $10 \mathrm{~kg}$ of kernels to 12.5 or 15 $\mathrm{kg}$ resulted in permeable coatings. In another study, ${ }^{9}$ involving deposition of pyrocarbon from propylene in a small coater at temperatures of $1250-1400^{\circ} \mathrm{C}$, it was found that open porosity increases with increasing hydrocarbon partial pressure and also with temperature at high hydrocarbon partial pressures.

Stinton $^{8}$ found that coating rate, hydrocarbon type, and deposition temperature influenced the anisotropy, $\mathrm{BAF}_{\mathrm{o}}$, with the strongest correlation being to coating rate. $\mathrm{BAF}_{\mathrm{o}}$ decreases sharply as coating rate increases to a value of about $3 \mu \mathrm{m} / \mathrm{min}$, and then decrease asymptotically at higher coating rates. ${ }^{8}$ Based on data in Stinton, ${ }^{8}$ meeting the AGR-1 $\mathrm{BAF}_{\mathrm{o}}$ specification of $\leq 1.035$ would require a coating rate greater than about 3 $\mu \mathrm{m} / \mathrm{min}$. Anisotropy also decreases with increasing deposition temperature ${ }^{10}$ and below about $1350^{\circ} \mathrm{C}$, also decreases with decreasing gas flux. ${ }^{11}$

From the studies cited, it appears that process parameters that produce very isotropic pyrocarbon coatings lead to permeable coatings, while process parameters that produce impermeable coatings may have high anisotropy. Selection of variants for irradiation as part of AGR-1 tests will aim to determine the optimum IPyC coating conditions between these competing trends.

\section{$\underline{\text { SiC microstructure }}$}

$\mathrm{SiC}$ grain size and shape varies with coating temperature, coating rate, and hydrogen to MTS ratio. ${ }^{12,13}$ Grain size increases with increasing temperature. ${ }^{12,14}$ Grain size also increases with increasing coating rate at temperatures greater than about $1550^{\circ} \mathrm{C}$, but shows little change with changing coating rate at a temperature of $1500^{\circ} \mathrm{C} .{ }^{12}$ Higher temperatures produce a more columar grain structure whereas lower temperatures produce more equixed grains. ${ }^{12}$ Addition of argon to the hydrogen diluent gas has been reported to significantly decrease $\mathrm{SiC}$ crystallite size. ${ }^{15}$ 
SiC coatings produced at low (e.g., 25:1) hydrogen to MTS ratios or low temperatures $\left(<1400^{\circ} \mathrm{C}\right)$ ratios show a highly banded microstructure, while coatings at higher hydrogen to MTS ratios (e.g., 45:1) and higher temperatures (e.g., $1575^{\circ} \mathrm{C}$ ) had few bands. ${ }^{13}$ In another study, ${ }^{18}$ as the hydrogen to MTS ratio was increased progressively from 5 to 25 , the coatings showed less porosity and had smoother surfaces.

$\mathrm{IPyC} / \mathrm{SiC}$ interface

The intrusion of SiC into the outer IPyC layer seen in images of German particles suggest a high open porosity in this thin region of the pyrocarbon layer. Open porosity in turn suggests that at the end of the IPyC deposition there may have been a short period of increasing temperature or increasing hydrocarbon coating gas concentration.

\section{References}

${ }^{1}$ Technical Program Plan for the Advanced Gas Reactor Fuel Development and Qualification Program, ORNL/TM2002/262, April 2003.

${ }^{2}$ Hunn, J. D., Results From ORNL Characterization of German Reference Fuel From EUO 2358-2365 Composite, ORNL/CF-04/06, April 2004.

${ }^{3}$ Saurwein, J., L. Shilling, Final Report - Testing of As-Manufactured NPR-PTF, German, and U.S Historical Fuel Particles, GA 910647, September 30, 1993.

${ }^{4}$ Clark, C. R., Microstructural Evaluation of As-Manufactured Fuel Particles, Final Report, BWED-93-032, Rev. 1, June 22, 1993.

${ }^{5}$ Fuel performance and Fission Product Behaviour in Gas Cooled Reactors, IAEATECDOC-978, November 1997.

${ }^{6}$ Huschka, H., P. Vygen, Coated Fuel Particles: Requirements and Status of Fabrication Technology, Nuclear Technology 35, September 1977, pp.238-245.

${ }^{7}$ Stinton, D. P., B. A. Thiele, W. J. Lackey, C. S. Morgan, Detection and Control of AsProduced Pyrocarbon Permeability in Biso-Coated High-Temperature Gas-Cooled Reactor Fuel Particles, Bulletin of the American Ceramic Society 61, 1982, pp. 245-250.

${ }^{8}$ Stinton, D. P., W. J. Lackey, B. A. Thiele, Influence of Process Variables on Permeability and Anisotropy of Biso-Coated HTGR Fuel Particles, ORNL/TM-6087, November, 1977

${ }^{9}$ Ford, L. H., C. F. Bilsby, Porosity Related to Structure for Low Temperature Propylene Pyrocarbons, Journal of Nuclear Materials 60, 1976, pp. 79-88.

${ }^{10}$ Lackey, W. J., D. P. Stinton, J. D. Sease, Improved Gas Distributor for Coating HighTemperature Gas-Cooled Reactor Fuel Particles, Nuclear Technology 35, September 1977, pp.227-237 
${ }^{11}$ Pratt, R. B., J. D. Sease, W. H. Pechin, A. L. Lotts, Pyrolytic Carbon Coating in an

Engineering-Scale System, Nuclear Applications 6, 1969, pp. 241-255.

${ }^{12}$ Lauf, R. J., D. N. Braski, Characterization of SiC Coatings on HTGR Fuel Particles: Final Report, ORNL/TM-7571, January 1981.

${ }^{13}$ Stinton, D. P., W. J. Lackey, Effect of Deposition Conditions on the Properties of Pyrolytic SiC Coatings for HTGR Fuel Particles, Bulletin of the American Ceramic Society 57, 1978, pp. 568-573.

${ }^{14}$ Gulden, T. D., Deposition and Microstructure of Vapor-Deposited Silicon Carbide, Journal of the American Ceramic Society 51, 1968, pp. 424-427.

${ }^{15}$ Ford, L. H., N. S. Hibbert, D. G. Martin, Recent Developments of Coatings for GCFR and HTGCR Fuel Particles and Their Performance, Journal of Nuclear Materials 45, (1972/73) pp. 139-149.

${ }^{16}$ Bathesen, E., HTR Fuel Element Development in the Federal Republic of Germany, Behaviour of gas cooled reactor fuel under accident conditions, Proceedings of a specialists meeting held in Oak Ridge, November 5-8, 1990, International Atomic Energy Agency, Vienna, International Working Group on Gas-Cooled Reactors, IWGGCR--25.

${ }^{17}$ Heit, W., H. Huschka, A. W. Mehner, HTR Fuel Manufacturing Experience, Specialists' meeting on gas-cooled reactor fuel development and spent fuel treatment, Moscow, Oct 18-21, 1983, International Atomic Energy Agency, Vienna, International Working Group on Gas-Cooled Reactors, IWGGCR--8.

${ }^{18}$ J. I. Federer, SiC Coating Process, Gas-Cooled Reactor Programs Annual Progress Report for Period Ending December 31, 1973, ORNL-4975, pp. 79-82.

${ }^{19}$ Nabielek, H., G. Kaiser, H. Huschka, H. Ragoss, M. Wimmers, W. Theymann, Fuel for

Pebble-Bed HTRs, Nuclear Engineering and Design 78, 1984, pp. 155-166. 